\title{
A COMPARATIVE INVESTIGATION IN MEASURING FOOD ACCESS: FOOD DESERTS IN URBAN SETTING
}

By

Amirmohsen Behjat

M.S.c Razi University, Iran, 2005

B.S.c Shiraz University, Iran, 2002

\begin{abstract}
A Thesis
Presented to Ryerson University
\end{abstract}

In particular fulfillment of the

Requirements for the degree of

Master of Applied Science

In the Program of

Environmental Applied Science and Management

Toronto, Ontario, Canada, 2012

(C) Amirmohsen Behjat 2012 


\section{Author's Declaration}

I hereby declare that I am the sole author of this thesis. This is a true copy of the thesis, including any required final revisions, as accepted by my examiners.

I authorize Ryerson University to lend this thesis to other institutions or individuals for the purpose of scholarly research

I further authorize Ryerson University to reproduce this thesis by photocopying or by other means, in total or in part, at the request of other institutions or individuals for the purpose of scholarly research.

I understand that my thesis may be made electronically available to the public. 


\title{
A COMPARATIVE INVESTIGATION IN MEASURING FOOD ACCESS: FOOD DESERTS IN URBAN SETTING
}

\author{
Amirmohsen Behjat \\ Master of Applied Science in the Program of \\ Environmental Applied Science and Management \\ Ryerson University, Toronto, 2012
}

\begin{abstract}
An increasing number of food desert studies over the past two decades have attempted to identify urban areas with inadequate access to nutritious and affordable food with implications for public health social equity and environmental issues. Due to different ways of operationalizing food desert analysis and the multifaceted dimension of the concept, there are inherent ambiguities in the validity and accuracy of food desert results across different studies. This study challenged the conventional measurements of food availability (e.g., distance-to-supermarket criterion) and food accessibility (e.g., circular buffer method) in identifying food deserts. An alternative methodology was developed that considered a wider variety of healthy food sources and used a network buffer method to produce more comprehensive results. Using Geographic Information System (GIS) analysis, alternative measures of food deserts were tested empirically in one Toronto 'disadvantaged' neighborhood. The results indicated that different areas were identified as part of a food desert depending on the methodology used. It concludes that failing to use a broader set of food desert elements can significantly alter the results in the study area.
\end{abstract}




\section{Acknowledgments}

I would like to thank Dr. Mustafa Koc, my extremely patient, dedicated, compassionate, supervisor and friend, who has taught me so much over the last several years; to my thesis third reader, Dr. Ronald Pushchak, provided careful feedback and insights that strengthened this overall document.

I would also like to thank Dr. Shuguang Wang, my thesis second reader, for his guidance and steadfast encouragement to complete this study. A special thank you to my committee chair, Dr. Michal Bardecki, for his support and contribution.

Finally, I would like to thank my wife, Arefeh Pasyar. She was patient when necessary, assertive when appropriate, and comforting when needed. 


\section{Table of Contents}

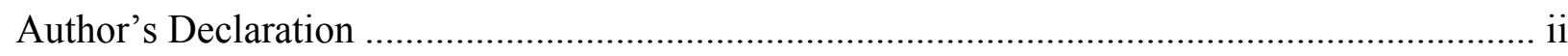

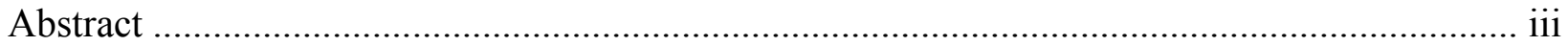

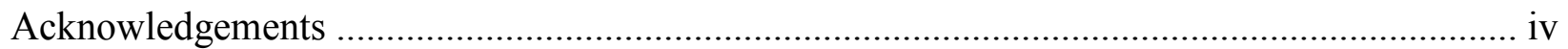

Table of Contents

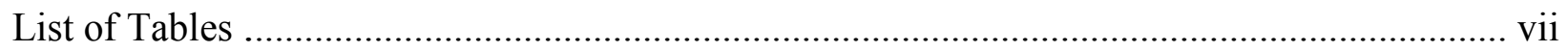

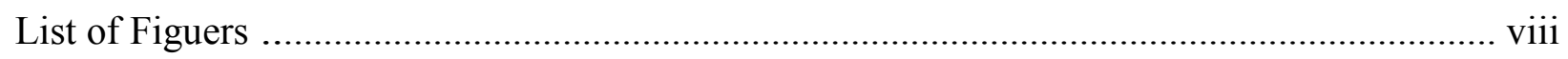

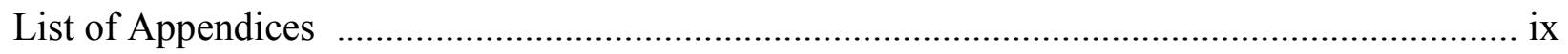

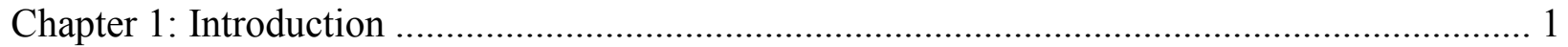

1.1 The Origin and Definitions of Food Desert.................................................................. 2

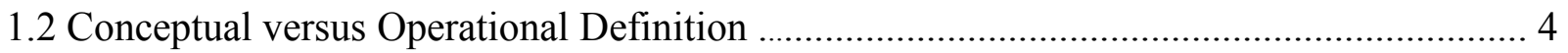

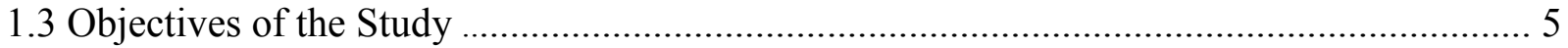

Chapter 2: Significance of Food Desert Studies ................................................................... 7

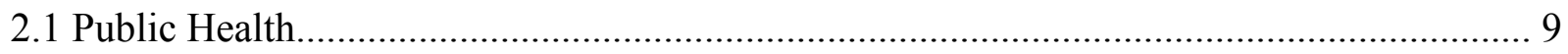

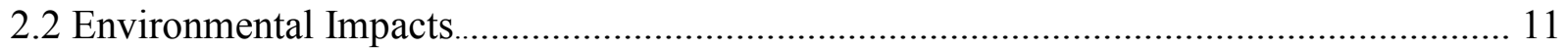

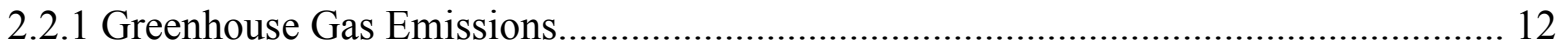

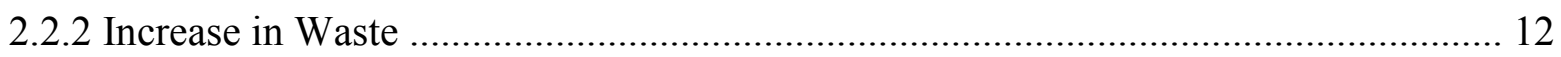

Chapter 3: Challenges in Identifying Food Deserts …………………………………......... 14

3.1 Elements in Identifying Food Deserts ........................................................................ 14

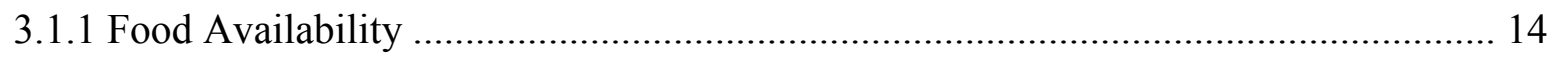

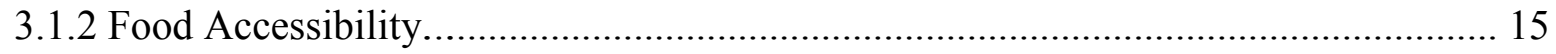

3.1.2.1 Measure of Accessibility to Food Stores..................................................................16

3.1.2.2 Defining Reasonable Walking and Driving Distances...........................................16

3.1.2.3 Measuring Distance: Euclidian and Network Street.................................................17

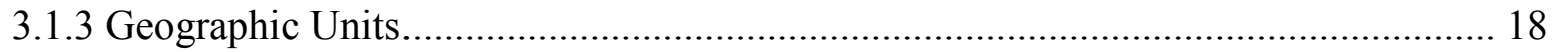

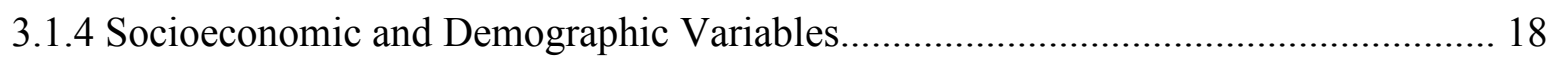

3.2 Complexities in Measuring Food Access and Identifying Food Deserts............................ 19

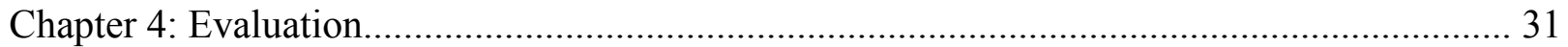

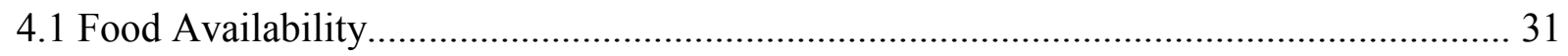

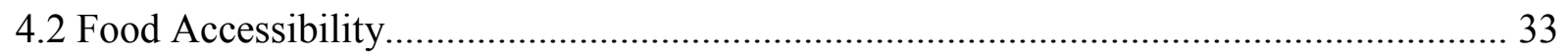




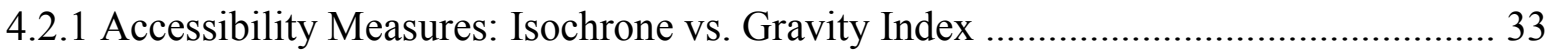

4.2.2 Accessibility Parameters: Defining Buffer Size .............................................. 34

4.2.3 Comparing Circular and Network Buffers...................................................... 35

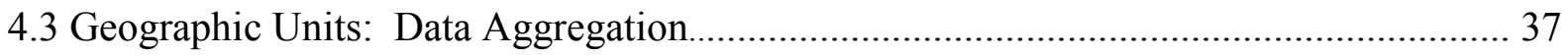

4.4 Socioeconomic and Demographic Variables............................................................ 38

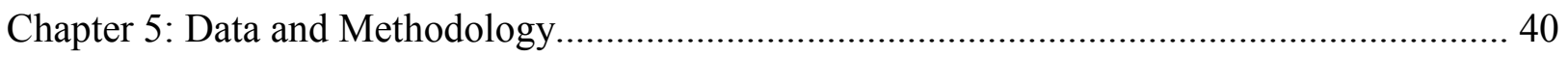

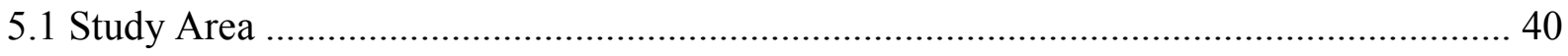

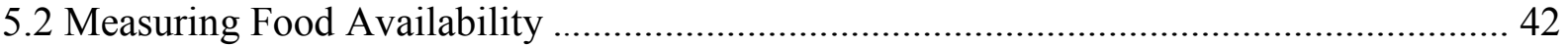

5.2.1 Data Preparation for Food Stores.....................................................................43

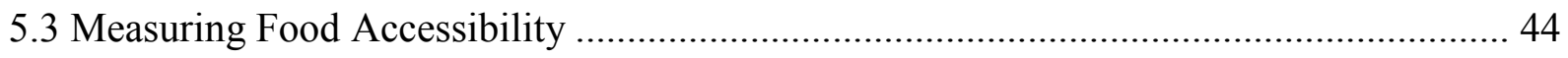

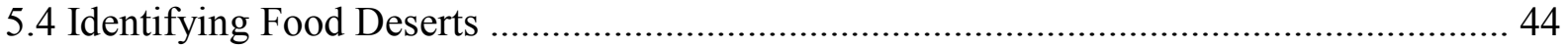

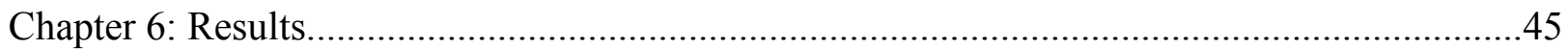

6.1 Difference in Measuring Food Availability............................................................46

6.2 Difference in Measuring Food Accessibility ................................................................48

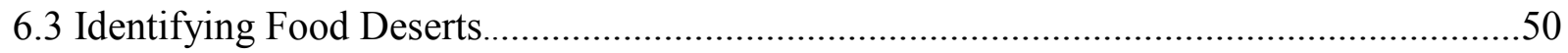

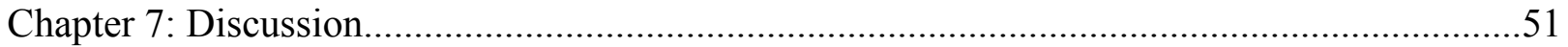

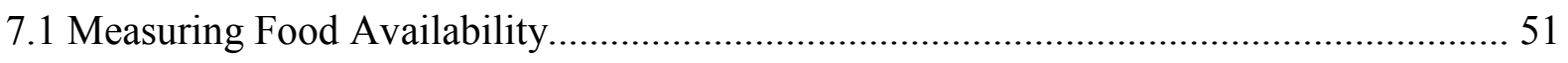

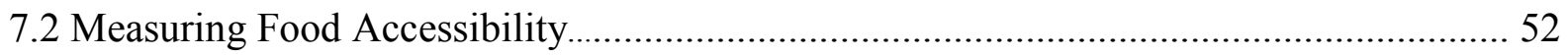

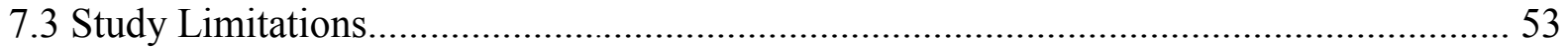

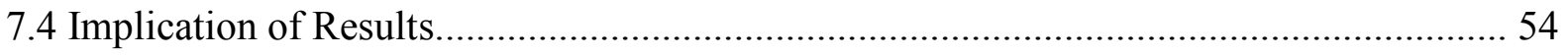

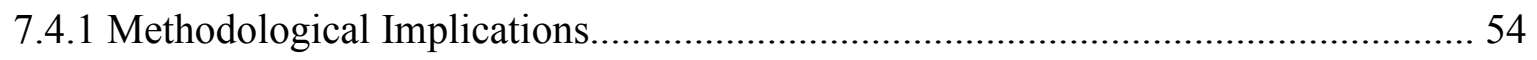

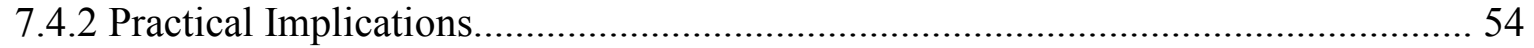

7.5 Recommendations for Future Studies.................................................................... 55

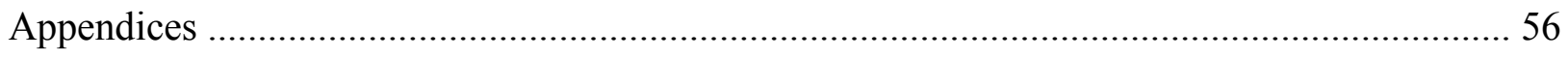

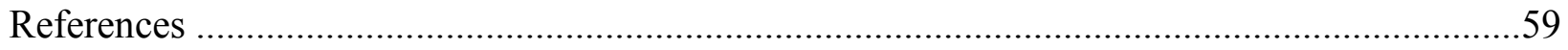




\section{List of Tables}

Table 3.1: Summary descriptive table of food access/food desert measurements studies included

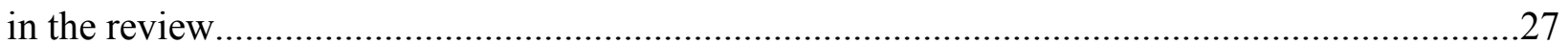




\section{List of Figures}

Figure 3.1: Euclidian and Network Distances............................................................. 18

Figure 4.1: Circular Buffer (A) vs. Network Buffer (B).................................................. 36

Figure 5.1: Geographic Location of Englemount-Lawrence Neighbourhood............................ 28

Figure 6.1: Map of Food Deserts in Study Area Based on Chen (2011) Definition................... 46

Figure 6.2: Food Deserts: Based on Study Operetionalizing of Food Availability .............. 47

Figure 6.3: Food Deserts: Chen (2011) vs. Study Operetionalizing of Food Accessibility........ 49

Figure 6.4: Food Deserts in the Englemount-Lawrence Neighbourhood................................ 50 


\section{List of Appendices}

Appendix A: Disadvantaged Areas in the city of Toronto.......................................... 56

Appendix B: Ethnic Stores and Specialty Stores in the Englemount-Lawrence Neighbourhood.57 


\section{Chapter 1: Introduction}

Food is of the utmost importance as it is a basic need in sustaining human life. People need food in order to get the essential nutrients and necessary energy to carry out their daily activities. Access to food that provides a safe, healthy and nutritiously adequate diet is essential for food security and public health. The Food and Agricultural Organization of the United Nations defines food security as a condition "that exists when all people, at all times, have physical, social and economic access to sufficient, safe and nutritious food that meets their dietary needs and food preferences for an active and healthy life" (FAO, 1996).

While it is difficult to identify healthy and nutritiously adequate foods, "usually fresh or minimally processed foods, naturally dense in nutrients, that when eaten in moderation and in combination with other foods, sustain growth, repair and maintain vital processes, promote longevity, reduce disease, and strengthen and maintain the body and its functions" are considered healthy (ATHFC, 2010). The U.S. Department of Agriculture listed some foods, such as fruits, vegetables, whole grains, fat free or low-fat dairy, and lean meats that are perishable (fresh, refrigerated, or frozen) or canned, as well as nutrient-dense foods and beverages, as healthy foods (USDA, 2010).

Two of the most common sources of healthy food options for people living in urban neighbourhoods are supermarkets and grocery stores because they provide the most reliable access to a wide variety of nutritious and affordable produce and other food options; although people can also obtain healthy food items from small food retailers (e.g., ethnic stores, specialty stores) and farmers' markets (Ver Ploeg, 2009).

Unfortunately, due to the uneven distribution of healthy food outlets and physical, financial and social barriers, not all neighbourhood residents have equal access to nutritious and affordable 
foods as one of the major key elements of community food security. An area where residents have limited access to healthy and affordable foods is called a 'Food Desert' (Cummins and Macintyre, 2002). In these areas residents usually obtain food through fast-food outlets and higher-priced convenience stores which mostly supply unhealthy and 'junk' foods (Lister, 2007). The problem of food insecurity is more likely to occur in communities or neighbourhoods that are classified as food deserts (Springler, 2011). A better understanding of food deserts can provide guidance about communities that may suffer from food insecurity (Stielly, 2012). In this sense, the food desert concept as a symptom of community food insecurity can be used by policy makers and service agencies to identify neighbourhoods at potential risk of food insecurity (Bedore, 2007). Gallaher (2008) stated that a "food desert is important to every type of community- urban, suburban, and rural- because findings from our studies reveal that residents of food deserts suffer worse from diet-related health outcomes including diabetes, cancer, obesity, heart diseases and premature death" (p. 1). Moreover, some scholars addressed the significant impact of a food desert on the environment aspects such as greenhouse gas emissions and increase in municipal solid wastes (e.g., McCreary and Briarpatch, 2006; Herrington, 2012).

\subsection{The Origin and Definitions of Food Desert}

In the past two decades, the concept of food desert has been attracting the attention of urban researchers interested in understanding the causes and consequences of neighbourhoods with limited access to food. The first use of the term 'food desert' was attributed to residents of a public sector housing scheme in the West of Scotland in the early 1990s (White, 2007). It was picked up and used by the Policy Working Group of the Government's Low Income Project Team of the Nutrition Task Force in 1995 (Beaumont et al., 1995). Early research in Britain provided the first technical definition, identifying a food desert as a "poor urban area, where 
residents cannot buy affordable, healthy food" (Cummins and Macintyre, 1999 cited in Philips, 2011). In North America, Blanchard first used the phrase "food deserts" in order to describe rural areas of Mississippi that were outside of supermarket service areas (Blanchard, 2006). Since then, the phrase has been used from different perspectives by scholars, depending on the nature of the study. Below are some of the examples of its usage in rural and urban areas that vary by country of consideration:

- Hendrickson et al. (2006), defined food deserts as "urban areas with 10 or fewer stores and no stores with more than 20 employees".

- Morton and Blanchard (2007) defined rural food deserts as "counties in which all residents live more than 10 miles to the nearest supermarket chain or supercenter".

- Gallagher (2008), defined food deserts as "large geographic areas that have no or distant mainstream grocery stores".

- Large geographic areas where mainstream grocery stores are scarce or missing (Trimarchi, 2008)

- A low-income census tract where a substantial number or share of residents has low access to a supermarket or large grocery store (USDA, 2011)

Shaw (2006) went beyond the conventional definitions of food desert and argued that it is not only a matter of the presence or absence of supermarkets and grocery stores in a neighborhood; the other socioeconomic and demographic factors should be included in defining food deserts. She believes that physical, financial and cultural factors, and the knowledge of residents can be preventive factors that limit residents' access to healthy food options. These factors can be described as follows: 
1) Ability: Any physical barriers that prevent residents from having access to healthy foods such as personal disability, geographic location of food stores (e.g., road crossings, highways), and weight of food to be carried home.

2) Assets: Financial obstacles such as paying for the cost of transportation to travel to food stores, higher prices for healthy food options and lack of space for food storage.

3) Attitude: Any state of mind such as inadequate knowledge of healthier food, cultural and religious matters, time constraints and fear of neighborhood crime.

\subsection{Conceptual versus Operational Definition}

Although the term food desert implicitly means areas where residents do not have easy access to healthy food options, there is still no consensus in terms of a standard definition among researchers. Large variation in the approaches and techniques used by researchers in the definition and operationalization of defining food deserts creates a challenge in providing reliable measurements and hence lead to diverse opinions on the extent of the problem and its location. Since the mid-1990s, there has been a growing interest in Britain to identify areas within cities and neighbourhoods that have limited access to healthy food options (Beaumont $e t$ al., 1995). Levin (2011) argues that the concept of the food desert is still imprecise and openended in related studies. Similarly, Reisig and Hobbiss (2000) stated that " the term has remained conceptual rather than being an operational term by which geographical areas can be identified, and indeed is proving hard to define given that the ease with which people access food is a function of more than geography" (p. 137). The lack of consensus in terms of an operational definition of food deserts makes it particularly difficult to develop effective methods in measuring this concept (Sparks, 2008). 
Most researchers agree on using certain general characteristics in defining a food desert such 'poor or limited access', 'scarce stores', 'underserved areas', 'lack of healthy food', and 'lowincome residents'. For example, Guy and David (2004) introduced general criteria for a food desert as having residents who: 1) are physically and economically disadvantaged, 2) have poor nutrition, 3) are geographically disadvantaged, and 4) live in areas with a limited supply of foods. However, researchers face ambiguities in moving from conceptual to operational definitions of a food desert. For instance, it is not clear as to what kind of parameters or elements should be taken into consideration in order to measure 'limited or poor access' in a certain area. Rose et al, (2009) mentioned that depending on operationalized definitions, researchers can get different results in food desert studies. Leete et al. (2011) suggested four elements that should be taken into account in an operational definition of food deserts: (1) a geographic unit of analysis, (2) a definition of what constitutes a sufficiently wide range of nutritious foods items, (3) a threshold for determining low access to food, and finally, (4) a threshold for determining which populations with low food access will lack the resources to access food from more distant retail outlets. An example of an operationalized food desert definition, which has been implemented by Baltimore City's Food Policy Initiative and the Johns Hopkins Center for a Livable Future (2010) in Baltimore City, is an area that shares the following qualities:

- More than 1/4 mile from a major supermarket

- Median household income is at or below 185 percent of the federal poverty level

- 40 percent of households have no access to a vehicle

- The Healthy Food Availability Index for existing supermarkets and corner stores is low

\subsection{Objectives of the Study}

Through a review of some of the recent contributions to food desert literature, this paper tries to compare and classify alternative food access measurement techniques in identifying food deserts 
based on major common elements (e.g., availability, accessibility, socioeconomic variables and aggregation level) in urban areas. Although there is no consensus on operational definitions of food deserts (as discussed above), researchers in a variety of fields such as geography, urban planning, public health, business and social justice have identified a number of quantitative and qualitative indicators in measuring food access in order to identify food deserts (e.g., Apparicio, 2007; Gallaher, 2008; Kowaleski-Jones et al., 2009; McEntee and Agyeman, 2009; Shaw, 2006; Sparks, 2008; Woodham, 2009; Wrigley et al., 2002; Zenk et al., 2005). Different criteria such as acceptable walking distance, store size, and quality of the food in the retail outlets have been taken into consideration in order to define food deserts (Community Planning Studio, 2010).

Even in a certain geographical area, researchers tend to vary in terms of the methodologies and measurement techniques they employ in identifying food deserts. This creates inconsistencies, ambiguities, and confusion among NGO and local government representatives and policy makers who hope to benefit from the food desert literature in identifying food insecure communities and neighbourhoods. For this reason, comparison and classification of food access measurement techniques for identifying food deserts will be important not only for researchers who are seeking reliable and valid measurement tools, but also for policy-makers and practitioners who like to respond to community needs by providing appropriate services and policy measures. In this study, I will conduct an in-depth investigation on the methods of selecting and utilizing food desert elements through a comparative review of food desert studies. Moreover, developing alternative methodologies in identifying food deserts will be empirically tested in one of the Toronto neighbourhoods. 


\section{Chapter 2: Significance of Food Desert Studies}

In the previous chapter, I pointed out the confusion in conceptualizing and operationalizing food deserts. Despite its limitations, however, the food desert concept has been used by various researches as an effective tool for identifying food insecure communities. Although this study mainly focuses on comparative methodologies, in this chapter, I will provide insights on the uses of the food desert concept from environmental and public health perspectives. While food desert would affect the health and wellbeing of the individuals involved, they will nevertheless carry hidden costs for the society at large, in terms of long term public health care costs, greenhouse gas emissions, and waste management expenditures.

Rose et al. (2009) argues that food desert is a useful concept for investigating geographic access to healthy food and for identifying areas of poor access, which helps policy-makers to improve food security. Similarly, Thomas (2004) mentioned that the concept of a food desert is a powerful tool for identifying the spatial distribution of food insecurity within communities. Hamm and Bellows (2003) define community food security as "a condition in which all community residents obtain a safe, culturally acceptable, nutritionally adequate diet through a sustainable food system that maximizes community self-reliance, social justice, and democratic decision-making” . A study by Ramos et al. (2008) investigated the relationship between food deserts and food insecurity in Kingston, Ontario. The researchers concluded that food insecurity tends to be more pronounced in food desert areas especially after closure of the major grocery stores (IGA) in the study area. It is well-documented that supermarkets and grocery stores as major suppliers of affordable and healthy food play a crucial role in improving food security. A 
number of food desert researchers tried to understand why some supermarkets and grocery stores leave low-income neighbourhoods.

Richner (2012) stated that "the migration of middle and upper class residents to suburban neighborhoods [suburbanization] caused food deserts as the upper and middle classes were able to afford vehicles they began to leave city centers towards suburban areas. Subsequently, the large supermarkets and grocery stores soon followed suit, and the citizens in the poor inner-city areas were left with little resources for fresh foods". Moreover, a body of research shows that supermarkets are reluctant to operate in unprivileged neighbourhoods due to real and perceived challenges such as dynamic markets, financing, security issues (crime and shoplifting), workforce training, and the need for a large number of square feet and lots of parking (cost and limitation of space), which are difficult to find within city centers (Gustat, 2012; Jimenez et al, 2011; Sieloff, 2011). Although many U.S. studies showed that food deserts are more likely to occur in inner-cities, the results in Canada are mixed. For example, according to studies by Smoyer-Tomic et al., (2006) in Edmonton, Alberta; Apparicio et al., (2007) in Montreal, Quebec; and the Martin Prosperity Institute (2010) in Toronto, Ontario, residents with low socioeconomic status in inner-cities had the best access to supermarkets. In contrast, Larsen and Gililand (2008) in a longitudinal study in the city of London, Ontario and in a research project with collaboration of the Public Health Observatory and Health Promotion in the city of Saskatoon, Saskatchewan, it is found that food deserts exist in inner-cities due to suburbanization.

A few scholars have tried to describe the cause of food deserts through an economic lens. They found out that food deserts represent the interaction of supply and demand factors for healthy food as a normal good in a certain area. The demand-side factors that apply to residents include 
low- income status, high prices, cultural and taste preferences, and population density. On the other side, the supply-side factors that apply to food retailers are the high input costs of running a retail food outlet, which include labor, land, equipment, transportation, stocking, inventory, and wholesale product costs (Bitler and Haider, 2011; Thierolf, 2012; Chicago Policy Research Team, 2011).

\subsection{Public Health}

It is well-documented that dietary behaviour plays a crucial role in people's health and wellbeing (McGinnis and Nestle, 1989). A growing body of literature struggles to investigate the association between access to healthy food options and chronic diseases such as obesity, Type 2 diabetes, cardiovascular disease, cancers and hypertension in different food environments.

According to studies in Baltimore, New York City, and North Carolina, residents with no supermarket access within a mile of their neighbourhoods are 25 to 46 percent less likely to have a healthy diet than those with the most supermarket access in their neighbourhoods (Health Policy Connection, 2011). A similar study by Larson et al. (2009) in the U.S., found a strong correlation between access to healthy food options and dietary behaviours. Cummins and Macintyre (2006) indicated that there is a positive correlation between proximity to supermarkets

and the fruit and vegetable consumption of low-income households, and to some extent they have a better dietary pattern with increasing access to supermarkets. Michimi and Wimberly (2010) added that easy access to supermarkets not only increases fruit and vegetable intake, but also decreases the obesity rate among metropolitan residents.

Rundle et al. (2009) believe that in order to examine the association between dietary patterns or chronic diseases and access to healthy food options, the whole food environment (healthy and unhealthy food stores regardless of size) should be considered rather than just simply focusing on 
a few types of food stores. Galvez et al. (2009) also mentioned that the current poor health outcomes in U.S. neighbourhoods are associated with the presence of unhealthy food stores. Brown et al. (2008) investigated the associations between the neighbourhood food resource environment and the health status for adults with, and without, a chronic condition in Los Angeles. Based on their findings, both greater accessibility to, and shopping in, large, chain supermarkets were associated with better self-rated health status and a lower Body Mass Index (BMI). Macdonald et al. (2011) investigated whether proximity to food retail stores is associated with dietary patterns or BMI in Glasgow City, U.K. They found few statistically significant associations between proximity to food retail outlets and dietary patterns or obesity. Moreover, in contrast with U.S. studies, they indicated that fruit and vegetable intake was not higher with better access to fruit and vegetable stores or supermarkets.

In some U.S. studies, researchers have tried to make comparisons between the BMIs or obesity rates of residents who have access to healthy food outlets (such as supermarkets and grocery stores) and residents who have access to unhealthy food outlets (such as convenience stores, corner stores and fast foods). Most of them indicated that lower BMIs and obesity rates of residents are highly correlated to access to healthy food outlets and higher BMIs, and obesity rates of residents are correlated with access to unhealthy food outlets (Morland et al., 2006; PolicyLink, 2009; Raja et al., 2010).

According to a comprehensive study by Woodham which was conducted in Eastern Porirua and Whitby (two desperate areas of Porirua, New Zealand), the Retail Food Environment Index (RFEI) - the ratio of 'unhealthy' to 'healthy' food outlets was developed and calculated for both areas. The results indicated that there were more 'unhealthy' food outlets in Eastern Porirua than Whitby and more supermarkets in Whitby than Eastern Porirua. Additionally, the RFEI was 
lower for most neighbourhoods in Whitby compared with Eastern Porirua (Woodham, 2009). Similarly, Gallagher developed the term 'Food Balance' in order to describe food environments and subsequently define food desert in Chicago. She added that Food Balance Score (FBS) is the average distance to any mainstream food venue (e.g., small, medium, and large grocery stores and supermarkets) divided by the average distance to a fringe food venue (e.g., gas stations, liquor stores, party stores, dollar stores, bakeries, pharmacies, convenience stores). Based on the

description, in a food balance environment, the distance between grocery stores and supermarkets is roughly the same as the distance to fringe food suppliers. The results showed that diet-related health outcomes such as higher BMI and premature death by diabetes more often occurred in communities with a food imbalance (closer distance to fringe food venues than mainstream food venues in a community), even after accounting for differences in income, education, and race (Gallagher, 2007).

Aside from chronic diseases as a health impact of food deserts, recently very few studies argued that there is a strong association between getting infected with gastro-intestinal illnesses and living in food desert areas (Gillespie et al., 2010; Darcey, 2010). However, as their claim is relatively recent and challenging, future studies need to be conducted to examine the correlation between access to healthy food options and gastro-intestinal illnesses.

\subsection{Environmental Impacts}

Although most studies focus on the health outcomes of food deserts and limited access to healthy food options, a few studies investigated the environmental impacts of food deserts. The results indicate that food deserts and access to unhealthy food options have significant negative 
environmental impacts in terms of waste and greenhouse gas emissions (e.g., Hickman, 2007; PlaNYC, 2011).

\subsubsection{Greenhouse Gas Emissions}

In a food desert study in the city of Saskatoon by McCreary and Briarpatch (2006), the results suggested that if the residents in inner-city communities do not have access to healthy food options, they have to drive extraordinary distances to find food and greenhouse gas emissions will inevitably continue to increase. According to Food Secure Canada (2012), food deserts in cities and suburbs that force people to travel or drive out to the edge of town for healthy foods increase fossil fuel energy use, pollution, and greenhouse gas emissions. Weatherspoon et al. (2010) indicated that due to the lack of healthy food retailers in inner-city Detroit, the environmental cost of the extended driving distance for those who drive to suburban markets, in fuel and pollution, carbon footprint and road wear, waste management and lost recycling is estimated at $\$ 1$ billion.

Vallianatos et al. (2004) in Los Angeles County (cities of Inglewood, Los Angeles and Rosemead) mentioned that big-box stores the size of Wal-Mart Supercenters can generate 1,000 car trips per hour and 10,000 trips per day. They added that as Wal-Mart and most other big box stores are not pedestrian-friendly, nor are they conducive to the use of public transportation, they cause heavy traffic and contribute to greenhouse gas emissions.

\subsubsection{Increase in Waste}

Shortage of healthy food is not the only problem of a food desert. In communities where residents have no or limited access to fresh produce and healthy food options, typically the 
residents rely on fast food restaurants and convenience stores that offer few or less healthy food choices (Getz, 2008; Sterling and Grover, 2011).

In a study by researchers of the University of Ottawa (2011) in the city of Ottawa, the results indicated that fast foods caused increasingly more solid waste as a result of processing, packaging, and shipping. Similarly, Naaz (2012) mentioned that junk foods are usually served in packets and the materials used for packing junk foods contribute to a considerable amount of waste. Fast food waste has negative impacts on the marine environment. Styrofoam plastic, a staple of fast foods, becomes a permanent part of our environment when littered as it is a nondegradable form of waste. Eventually it reaches the ocean through the drains; the plastics from this urban pollution are the largest source of marine debris. Some of the consequences of these environmental contaminants are associated with entanglement, ingestion, suffocation and general debilitation (Gregory, 2009; Herrington, 2012).

Most landfills in North America are quickly filling up and many of them have already closed down. On the other side, when residents in a community have access to fresh foods and healthy options, their kitchen wastes such as fruit and vegetable scraps and peelings, and egg shells which usually go to landfills can be simply converted to compost in three to six months as a natural alternative to some chemical fertilizers. By composting as a win-win scenario, not only is more than $30 \%$ of household wastes reduced but it also improves soil organic matter content and soil structure (Cassidy and Patterson, 2008; Eartheasy, 2012; Stan et al., 2009). 


\section{Chapter 3: Challenges in Identifying Food Deserts}

While there is some general agreement on conceptual definitions of food deserts, difficulties arise when researchers try to operationalize the concept in developing the methodology to identify food deserts. As explained in the previous chapter, depending on the employed food desert element (e.g., availability, accessibility, geographic area, and socio economic variables) in operationalizing the food desert definition, the results can be inconsistent even in the same area. For example, in a comprehensive study by Rose et al. (2009), four different food desert definitions were operationalized to classify eight census tracts in New Orleans. The results indicated that only one tract (in Uptown) was never classified as a food desert and only one tract (in the Lower Ninth Ward) was always classified as a food desert. The other six tracts were periodically classified as food deserts. Citywide, food desert rates (the percentages of city land which were classified as food deserts) ranged from $17 \%$ to $87 \%$ based on the operational definition. Similarly, Kowalesiki-Jones et al. (2009) operationalized three alternative definitions to identify food deserts in Salt Lake County, Utah. According to the findings, food deserts varied across neighbourhoods depending on the food deserts elements used. In order to understand the challenges in identifying food deserts that make the results less generalizeable and inconsistent, in the first section of this chapter I introduce the major common food desert elements that researchers typically use in developing methodologies to identify food deserts across studies.

\subsection{Elements in Identifying Food Deserts}

\subsubsection{Food Availability}

The food environment includes the home (which is especially important for younger adults, and adolescents), school, work, and anywhere else a person might eat. In food desert studies, however, the food environment is limited to geographical units (e.g., neighbourhood, census 
tract) and food resources. The food environment includes different types of food stores, restaurants, schools, and worksites (Nikhanj, 2010). In order to characterize the food environment in certain areas, researchers used detailed industry codes or business directories to classify food stores in terms of the degree to which they offer healthy or unhealthy food (Kowalesiki-Jones et al., 2009). In food store classifications, supermarkets and grocery stores were assumed to supply healthy food options in most studies although in some other studies small food retailers (e.g., specialty stores, ethnic stores) were also considered as providers of healthy foods. For instance, one of the most frequent definitions in classifying supermarkets and grocery stores in food desert studies were developed by Food Marketing Institute (FMI). According to FMI (2002), a grocery store is "any retail store selling a line of dry grocery, canned goods or non-food items plus some perishable items." The FMI also defines a supermarket as "any full-line self-service grocery store generating a sales volume of $\$ 2$ million or more annually." Similarly, Nabhan and Watters (2011) used the USDA definition for food stores that supply healthy food options (full-service supermarkets or chain grocery stores that have 50 or more employees and gross $\$ 2$ million or more in food sales each year). In order to obtain complementary information regarding food stores, company websites and yellow page directories were also used in food desert studies.

\subsubsection{Food Accessibility}

Food accessibility is defined as the ease of obtaining healthy food options in a given neighbourhood (Farley et al., 2009). The term food accessibility for neighbourhood residents is interpreted in food desert studies as the physical accessibility of food stores which supply healthy

food options. Geographical factors (i.e., food stores locations) and the accessibility gap (i.e., food stores distribution) have been frequently analyzed across studies (Wendt et al., 2008). 


\subsubsection{Measure of Accessibility to Food Stores}

Researchers measure food accessibility to link the residents to the food stores (Rose et al., 2009). In food desert studies, proximity and/or density of healthy food stores were generally used to define adequate access to healthy food options in a given area, although in a number of other studies competition has been included as well (e.g., Apparicio et al., 2007). The proximity approach assesses the distance to food stores by measuring distances, whereas the density approach quantifies the availability of food stores or travel times within a food environment (Charreire et al., 2010).

\subsubsection{Defining Reasonable Walking and Driving Distances}

In food desert studies, the main focus is on distance-based measurements. Thus, the question that usually arises is: What are the reasonable walking and driving distances to a food store? Researchers developed a time-based distance measure equivalent for both walking and driving. A 15-minute walk was assumed to be equal to 1000 metres in distance, with a walking speed of 4 kilometres per hour. For drivability, researchers assumed a point-to-point driving speed of 60 kilometres per hour; thus, reasonable access when driving is 15 kilometres, when using the walking distance equivalent (Ver Ploeg, 2009). However, in some studies multiple thresholds of reasonable walking and driving distances have been defined (e.g., Eisenburg and Silcott, 2010; Herries, 2010). In food desert studies, reasonable walking and driving distances are used to define the buffer size. Buffers are boundaries placed around areas (e.g., the boundary of a geographic unit) or points of interest (e.g., food stores or the centroid of a geographic unit). For

example, the number of food stores within a buffer (density) might be used to estimate a household's accessibility to food stores (Thornton et al., 2011). 


\subsubsection{Measuring Distance: Euclidian and Network Street}

Distances can be measured in three forms: Euclidean distance, Network distance, and Manhattan distance. Manhattan distance is rarely used in food desert research (e.g., Zenk et al., 2005) since it is generally meaningful only on a grid system, which only holds strictly in a few urban environments. Euclidean distance is the straight line distance ("as the crow flies") measures between points of interest and destinations, while Network distance, which is a more realistic representation of movements between points of interest and destinations, is the distance between origins and destinations measured along a transportation network, usually using the shortest path (Levinson and El-Geneidy, 2009). In most food desert studies, in order to create the buffers for capturing different type of food stores in the food environment, researchers have used a predefined scale using either Euclidean or Network method (also referred as constructing the buffer shape) to measure the reasonable walking and driving distances to food stores (Thornton et al., 2011). The application of each method in identifying food deserts, advantages, and drawbacks will be discussed in detail in the next chapter. The difference between Euclidian and Network distances are shown in Figure 3.1. 
Figure 3.1: Euclidian and Network Distances
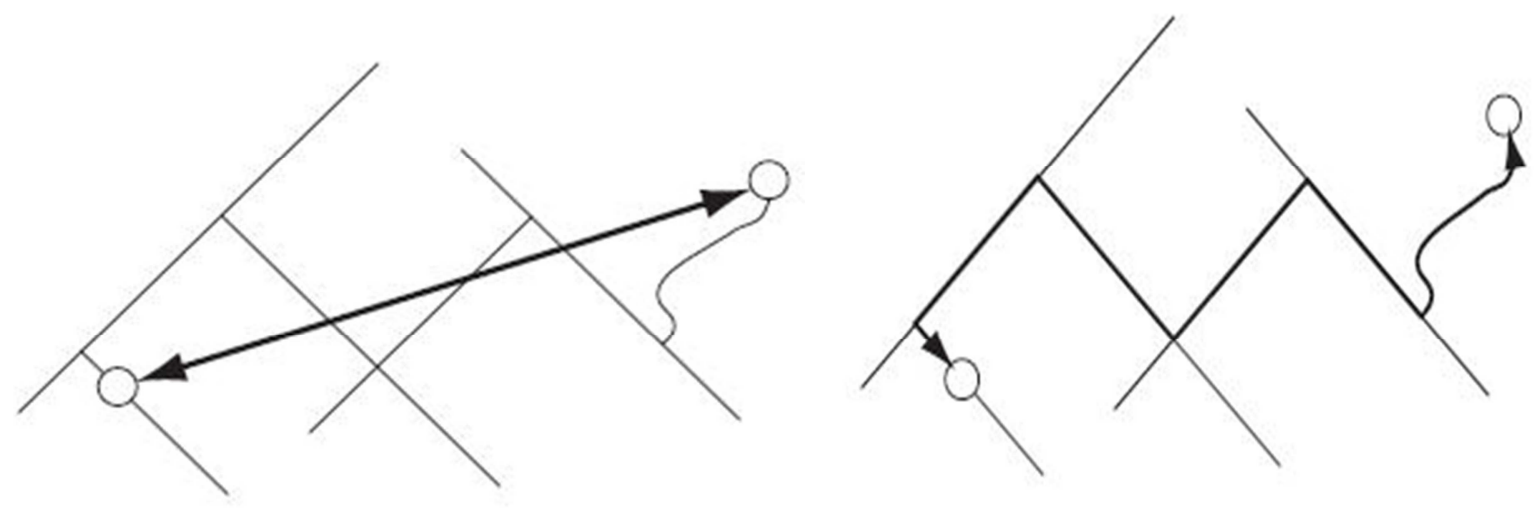

Source: Levinson and El-Geneidy, (2009, P. 16)

\subsubsection{Geographic Units}

In order to assess the food environment, researchers used a variety of geographical units based on available census data in different countries. In Canadian studies, census tract (e.g., Apparicio et al., 2007; Larsen and Gilliland, 2007; Martin Prosperity Institute, 2010) and its subdivisions such as enumeration area (EA) and dissemination area (DA) (e.g., Kershaw et al., 2010; Wintle, 2010) have been used as proxies of neighbourhoods. It should be noted that the EA was replaced by the DA as the smallest geographic unit for dissemination after the Canada Census in 1996. Few studies have used city-defined neighbourhoods to assess the food environment (e.g., Smoyer-Tomic et al., 2006). In U.S. studies, researchers used census tracts (e.g., Eisenburg and Silcott, 2010; Rose et al., 2009) in their subdivisions, such as block group (e.g., Gordon et al., 2010; Kowaleski-Jones et al., 2009; Russel and Heidkamp, 2011) and census block, which is the smallest geographic unit in United States Census Bureau hierarchy (e.g., Parsons, 2012; Leete et al., 2011). In the UK studies, electoral divisions (a geographic unit approximately equivalent to 
U.S. or Canadian census tracts) or the much finer postal code sectors or enumeration districts have been used (e.g., Clarke et al., 2002; Guy and David, 2004).

\subsubsection{Socioeconomic and Demographic Variables}

In the growing body of food desert studies, the association of access to healthy foods and residents' socioeconomic status have been investigated by a wide variety of methods and indices. Due to financial problems, many residents in disadvantaged neighbourhoods cannot afford the cost of various modes of transportation in order to have access to the distant food stores that supply nutritious and affordable foods. Socioeconomic (e.g., income, mobility resources, education, and employment) and demographic (e.g., age, sex, race/ethnicity) variables are the important factors that contribute to an area being a food desert which frequently used across studies. Blanchard (2006) stated "the socio-demographic characteristics of food desert populations provide information on the type of persons in food deserts and point to the specific policy needs of food deserts" (p. 9).

\subsection{Complexity in Measuring Food Access and Identifying Food Deserts}

According to what I discussed in Chapter 1, the operational definition of a food desert and the methods and data used to identify and characterize these areas varies drastically across studies, resulting in diverse opinions on the extent of the problem and its location. In order to better understand and compare how researchers measure food access and identify food deserts, in the second section of this chapter I classified and compared 26 food desert studies based on the major common and the most frequent food desert elements (e.g., availability, accessibility, data aggregation unit, and socioeconomic and demographic variables). The summary of each study is shown in (Table 3.1). 
In a study by Clarke et al. (2002) the pattern of food access and food retailing in two urban areas (Leeds/Bradford and Cardiff) was quantified in order to define food deserts. They drew a 500 metre circular buffer around each supermarket to represent a maximum reasonable walking distance for residents. They developed a deprivation score based on social class and car ownership of residents to define the disadvantaged areas. They identified six food desert areas where residents with high deprivation scores lived outside the buffer zone in terms of access to supermarkets. By assuming that healthy food options can only be found in supermarkets and grocery stores, Coombs et al. (2010) geocoded all supermarkets and grocery stores into a GIS layer and created one-mile radius buffers around them in Madison, Wisconsin. They argued that 'classic' food deserts were those beyond the one-mile radius buffer zones, without supermarkets and full-service grocery stores nearby. They added that in order to define food desert areas, automobile ownership, income level, and racial composition should be taken into consideration at the census block level. However, they left the food desert definition open and did not define any thresholds for the above variables.

In a comprehensive study in Nashville, Tennessee by Schlundt (2010), a Food Desert Score was developed at the census block level as an index to identify food desert areas in Nashville neighborhoods. Schlundt used the business license database to identify major grocery stores. At this point, a separate layer in GIS was created with just the major grocery stores, and a half-mile radius buffer was drawn around each store. He also calculated the proximity of each residential parcel to the nearest major grocery store and bus stop. Based on these calculations, he scored 460 census blocks on a scale of -37 to 60 (Food Desert Score) and a cut-off of 20 or greater was used as an index to identify food deserts. The results indicated that four food desert areas exist in Nashville (North Nashville, Edgehill, South Nashville, and East Nashville). 
According to a research project in Humboldt Park, Chicago (a pre-dominantly Puerto Rican neighborhood), a food desert is defined as a location that does not have a grocery store or other fresh produce vendor within 500 metres of walking distance. In order to operationalize food deserts in the study area, fresh produce addresses were geogoded into a GIS layer and a 500 metre radius buffer was drawn around each fresh produce point. The areas outside of the buffer zones were considered food deserts. The results indicated that food deserts were located in the South East and the North East of the Humboldt Park neighborhood (Knight et al., 2011). In a similar research project by Addy and Pike (2009) in the city of Maribyrnong, Melbourne, Australia, a food desert was defined to be an area outside a 500 metre radius buffer of an affordable and nutritious fruit and vegetable outlet. They geocoded all fruit and vegetable outlet addresses across the Maribyrnong municipality into a GIS layer. Residential land in the municipality that was located outside of the 500 metre buffer was identified as constituting food desert areas. Based on the results, three food deserts $(59 \%$ of the residential land in the municipality) were identified in the Maidstone, Braybrook, and Kingsville suburban areas.

In a study in the region of Waterloo, Ontario, Yousafzai et al. (2008) defined a food desert as an area where fresh food is either non-existent, too expensive, or inaccessible for the population with mean household income. The location of each supplier of fresh foods (e.g., supermarkets and grocery stores), residential area parcels, and bus stop locations within Regional Municipality of Waterloo (RMW) were obtained and imported to GIS. A buffer of 500 metre in radius was drawn around each fresh food outlet. The residents who live outside the fresh food buffer zones and who have no access to bus stops to obtain healthy foods were considered to be in a food desert. As a result, they created four separate food desert maps for RMW (Wellesley, Waterloo, Kitchener, and Cambridge). In terms of Kitchener, the Commercial Policy Review (2010) also 
identified food deserts in this area. The results of Kitchener food desert studies were slightly inconsistent when compared with the Commercial Policy Review as in the latter study 1000 metre radius buffers were utilized around healthy food outlets in order to identify and map food deserts.

Some studies identified food deserts in order to investigate the food security in a certain geographic area. For example, Wintle (2010) examined the association between food deserts and food insecurity in Northwestern Ontario (Thunder Bay region) in 1996, 2001, and 2006 (Canadian Census years) using Enumeration Areas (EA) and Dissimilation Areas (DA). Before identifying food deserts in selected areas, she created Accumulation Risk Factor (ARF) by including socioeconomic and demographic variables for each EA and DA as a primary index for potential food insecure communities. Then, healthy sources of food options were recognized and geocoded in GIS. A 500 metre ring buffer was drawn around each food outlet to identify food deserts based on residents who live outside the buffer zone and also have no access to public transportation. She concluded that food deserts are more likely to exist in EAs and DAs with a high ARF. Moreover, by comparing the food desert maps of 1996, 2001, and 2006, she showed that the food desert has declined in Northwestern Ontario communities. Another study by Ramos et al. (2008) focused on food security in Northern Kingston, Ontario by using quantitative (spatial access to food outlets) and qualitative (focus group) methodologies. They identified food deserts in the study area where low-income residents live outside the $500 \mathrm{~m}$ circular buffer zone of major grocery stores as the source of fresh foods. The results indicated that residents of Northern Kingston neighbourhoods suffer from food insecurity. Moreover, they concluded that food deserts and residents' education are the two most important barriers in improving food insecurity, specifically after the closing one of the major grocery stores (IGA) in the study area. 
In a comprehensive study in Montreal, Quebec, Appricio et al. (2007) suggested a methodology in order to identify food deserts in Montreal. After geocoding supermarket addresses into GIS, they measured geographical access based on proximity (distance to the nearest supermarket), density (number of supermarkets within a 1000 metre buffer) and competition in terms of food and prices (average distance to the three closest distinct chain-name supermarkets). The three accessibility measures from the centroid of blocks were calculated using the shortest network distance, which closely corresponds to the shortest path for going to a supermarket on foot. By developing a social deprivation index, combined with the three supermarket accessibility measurements, they sought to investigate food desert areas. The results showed that although access to supermarkets differs in each census tract, no severe food desert was found in Montreal. In a similar study by Smoyer-Tomic et al. (2006) spatial accessibility to supermarkets was calculated by using both the proximity (shortest network path to supermarket) and density (number of super markets within a 1000 metre network buffer around each postal zone centroid) methods in 212 Edmonton, Alberta neighbourhoods. They identified food deserts as neighbourhoods where residents have poor access to supermarkets (lowest quartile) and also belong to vulnerable subgroups (top quartile of low-income, lack of car ownership, and elderly people). Based on the results, only six neighbourhoods in the suburb area of Edmonton city were considered food deserts. In a study, Larsen and Gilliland (2008) measured supermarket accessibility in London, Ontario in 1961 and 2005, based on walking and public transit travel modes. GIS network analysis tool (was utilized to calculate the shortest path along the street network (proximity) and the number of supermarkets within 1000 metres of each block centroid (density). By creating a socioeconomic index within the census tract scale and assessing the level of supermarket accessibility, they identified a food desert in the city of London. The findings 
indicated that the East London neighbourhood has the poorest access to supermarkets and is still believed to be a food desert regardless of measurement types.

The University of Washington, Department of Urban Design and Planning (2011) conducted research in the Puget Sound region in Washington (State) in order to identify and map food deserts. After geocoding supermarket addresses into residential parcels, a half-mile street network buffer was applied around each supermarket. Researchers defined food deserts as areas of low-income: census blocks with more than 40 percent low-income households that have poor access to supermarkets. They concluded that most of food deserts are located in the suburbs of the study area, except for the King County where the majority of food deserts exist in urban areas. Anthony and Lee (2010) picked up the same methodology in identifying food deserts but defined different thresholds based on spatial and socioeconomic variables in the City of Los Angeles, California. They drew a one mile network buffer around each supermarket as a proxy of the service area. They identified food desert as block groups that are located outside the service area with a normalized poverty rate higher than 1.5 standard deviations of overall poverty rates for the population. The results indicated that food deserts are more likely to be found in the Downtown and Southeast Los Angeles neighbourhoods.

O'Dwyer and Coveney (2006) compared the availability and accessibility of supermarkets in four case study local government areas (LGAs) in Australia. After creating a 2.5 mile network buffer around each LGA, they used a driving travel mode to measure accessibility to supermarkets and subsequently identified food deserts in the study areas. Based on their operational definition of food deserts, a census tract with top quartile of the low-income residents who have no vehicular access is potentially a food desert, regardless of the proximity of the 
residents' homes to supermarkets. According to their findings dispersed and concentrated food deserts exist in three LGAs (Port Adelaide-Enfield, Onkaparinga, and Playford).

In some studies researchers tried to identify food deserts based on their own unique operational definition by incorporating supermarket/grocery store accessibility and socioeconomic and demographic variables. For example, in a study in Franklin County, Ohio by Eisenburg and Silcott (2010) different levels of food deserts were identified and mapped in the study area. In order to measure grocery store accessibility, they created multiple network buffers ( 0.25 mile, 0.5 mile, and 1 mile) to measure walk-to-store service area and multiple driving times (5 minutes, 10 minutes, 20 minutes) to measure drive-time to store. Drive time was scored $1-3$, with 3 being the longest drive time $(20 \mathrm{~min})$. An additional weight of 5 was given to drive times over 20 minutes. Walking also was scored 1, 2, 5, and 7. Additional weight was given for areas farther than 0.5 miles. By extracting socioeconomic and demographic variables within a census level, household income was scored $1-4$, car ownership $1-5$, and population density $1-6$. After adding all calculated scores, they classified food deserts as "Severe Food Desert Potential" (score of 23 - 25), "Strong Food Desert Potential” (20 - 22), "High Food Desert Potential” (17 - 19) and "Moderate Food Desert Potential" (14 - 16). They declared that although many residents live in vicinity of grocery stores, due to their poverty, lack of car accessibility and low population density, they are vulnerable to food insecurity in Franklin County. In another study, Gordon et al. (2010) developed a food desert index (FDI) based on components such as access to supermarkets, bodegas that supply healthy food options, and fast food restaurants within block groups in New York City. Each of the three food desert index components was ranked and scored according to the level of accessibility to healthy or unhealthy food options as low (1), medium (2), and high (3) on scale range of 3-9 (poor to high accessibility) within a quarter mile 
network buffer around center of each block group. They also examined the relationship between the block group socioeconomic and demographic variables (race/ethnicity and median household income), food desert index components, and a total food desert score. They calculated the lowest scores for East and Central Harlem, and North and Central Brooklyn neighbourhoods with the highest proportions of black residents and the lowest median household incomes. In contract, the most favourable food desert scores were calculated for the Upper East Side (a predominantly white, middle and upper-income) neighbourhood.

Baltimore City's Food Policy Initiative and the Johns Hopkins Center for a Livable Future (2010) also developed an operational food desert definition by determining the thresholds on the distance to food outlets, the quality and quantity of available food options and the socioeconomic variables at the block group scale for the city of Baltimore. Regardless of the absence or presence of a supermarket, the Healthy Food Availability Index (HFAI) scores for supermarkets, convenience, and corner stores were calculated based on the Nutrition Environment Measurement Survey (NEMS) on a scale of 0-26. A 0.25 mile network buffer was drawn around food outlets with HFAI scores above 8.8 (sources of healthy foods). Residential block groups with a median household income at or below 185 percent of the federal poverty level, and where $40 \%$ of households have no access to a vehicle, that are located outside the network buffer zone are identified as food deserts. The concept mapping results showed that block group food deserts are more likely to exist in the inner-city of Baltimore. 
Table 3.1: Summary Descriptive Table of Food access/Food Desert Measurements Studies Included in the Review

\begin{tabular}{|c|c|c|c|c|c|c|c|c|}
\hline \multirow[t]{2}{*}{ Reference (year) } & \multirow[t]{2}{*}{ Study Area } & \multirow{2}{*}{$\begin{array}{c}\text { Food Availability } \\
\text { (Food store Type(s)) }\end{array}$} & \multicolumn{3}{|c|}{ Food Accessibility } & \multirow{2}{*}{$\begin{array}{c}\text { Data Aggregation } \\
\text { Level }\end{array}$} & \multirow{2}{*}{$\begin{array}{c}\text { Socioeconomic \& } \\
\text { Demographic } \\
\text { Variables }\end{array}$} & \multirow[t]{2}{*}{ Findings } \\
\hline & & & $\begin{array}{c}\text { Access } \\
\text { Measure(s) }\end{array}$ & $\begin{array}{l}\text { Buffer } \\
\text { Size }\end{array}$ & $\begin{array}{l}\text { Buffer } \\
\text { Shape }\end{array}$ & & & \\
\hline $\begin{array}{l}\text { Addy \& Pike } \\
\text { (2009) }\end{array}$ & $\begin{array}{l}\text { Maribyrnong, } \\
\text { Melbourne }\end{array}$ & $\begin{array}{l}\text { Fruit and vegetable } \\
\text { stores } \\
\text { Take-away outlets }\end{array}$ & $\begin{array}{ll}- & \text { Proximity } \\
\text { - } & \text { Density }\end{array}$ & $500 \mathrm{~m}$ & Circular & Municipality & $\mathrm{N} / \mathrm{A}$ & $\begin{array}{l}\text { Food desert in } \\
\text { suburban area }\end{array}$ \\
\hline $\begin{array}{l}\text { Anthony \& Lee } \\
\text { (2010) }\end{array}$ & $\begin{array}{l}\text { Los Angeles City } \\
\text { California }\end{array}$ & Supermarkets & $\begin{array}{ll}\text { - } & \text { Proximity } \\
\text { - } & \text { Density }\end{array}$ & $1600 \mathrm{~m}$ & Network & Block Group & Household income & $\begin{array}{l}\text { Food deserts in } \\
\text { Downtown and } \\
\text { Southeast Los } \\
\text { Angeles }\end{array}$ \\
\hline $\begin{array}{l}\text { Apparicio et } \\
\text { al.(2007) }\end{array}$ & $\begin{array}{l}\text { Island of } \\
\text { Montreal, } \\
\text { Quebec }\end{array}$ & Supermarkets & $\begin{array}{ll}\text { - } & \text { Proximity } \\
\text { - } & \text { Density } \\
\text { - } & \text { Variety }\end{array}$ & $1000 \mathrm{~m}$ & Network & Census Block & $\begin{array}{ll}\text { - } & \text { Income } \\
\text { - } & \text { Lone-parent } \\
\text { families } \\
\text { - Unemployment } \\
\text { - Education }\end{array}$ & $\begin{array}{l}\text { No food desert } \\
\text { were identified }\end{array}$ \\
\hline $\begin{array}{l}\text { Baltimore City's } \\
\text { Food Policy \& } \\
\text { Johns Hopkins } \\
\text { Center (2010) }\end{array}$ & $\begin{array}{l}\text { Baltimore, } \\
\text { Maryland }\end{array}$ & $\begin{array}{l}\text { Supermarkets } \\
\text { Convenience stores } \\
\text { Corner stores }\end{array}$ & $\begin{array}{l}\text { - Proximity } \\
\text { - Density }\end{array}$ & $400 \mathrm{~m}$ & Network & Block Group & $\begin{array}{l}\text { - Household } \\
\text { income } \\
\text { - Car ownership } \\
\text { - Income }\end{array}$ & $\begin{array}{l}\text { Food desert in } \\
\text { inner-city area }\end{array}$ \\
\hline Chen (2011) & Toronto, Ontario & Supermarkets & Proximity & $1000 \mathrm{~m}$ & Circular & Census Tract & $\begin{array}{l}\text { - Immigration } \\
\text { - Unemployment } \\
\text { - Education } \\
\text { - } \quad \text { Car ownership }\end{array}$ & $\begin{array}{l}\text { Potential food } \\
\text { deserts in Toronto }\end{array}$ \\
\hline $\begin{array}{l}\text { Clarke et al. } \\
\text { (2002) }\end{array}$ & $\begin{array}{l}\text { Cardiff \& } \\
\text { Leeds/Bradford }\end{array}$ & $\begin{array}{l}\text { Co-operative stores } \\
\text { Grocery retails } \\
\text { Discount stores }\end{array}$ & $\begin{array}{l}\text { - Proximity } \\
\text { - Density }\end{array}$ & $500 \mathrm{~m}$ & Circular & Postal Sector & $\begin{array}{ll}\text { - } & \text { Household } \\
\text { income } \\
\text { - } & \text { Car ownership } \\
\text { - } & \text { Retired/Inactive }\end{array}$ & $\begin{array}{l}\text { Six problematic } \\
\text { food deserts: two } \\
\text { in Leeds/Bradford } \\
\text { and four in Cardiff }\end{array}$ \\
\hline $\begin{array}{l}\text { Coombs et al. } \\
\text { (2010) }\end{array}$ & $\begin{array}{l}\text { Madison, } \\
\text { Wisconsin }\end{array}$ & $\begin{array}{l}\text { Supermarkets } \\
\text { Full-service grocery } \\
\text { stores }\end{array}$ & $\begin{array}{l}\text { - Proximity } \\
\text { - Density }\end{array}$ & $1600 \mathrm{~m}$ & Circular & Census Block & $\begin{array}{ll}\text { - } & \text { Household } \\
\text { income } \\
\text { - } & \text { Car ownership } \\
\text { - } & \text { Race }\end{array}$ & $\begin{array}{l}\text { Classic food } \\
\text { deserts in } \\
\text { Southside \& } \\
\text { Eastside of } \\
\text { Madison }\end{array}$ \\
\hline
\end{tabular}




\begin{tabular}{|c|c|c|c|c|c|c|c|c|}
\hline \multirow[t]{2}{*}{ Reference (year) } & \multirow[t]{2}{*}{ Study Area } & \multirow{2}{*}{$\begin{array}{c}\text { Food Availability } \\
\text { (Food store Type(s)) }\end{array}$} & \multicolumn{3}{|c|}{ Food Accessibility } & \multirow{2}{*}{$\begin{array}{c}\text { Data Aggregation } \\
\text { Level }\end{array}$} & \multirow{2}{*}{$\begin{array}{c}\text { Socioeconomic \& } \\
\text { Demographic } \\
\text { Variables }\end{array}$} & \multirow[t]{2}{*}{ Findings } \\
\hline & & & $\begin{array}{c}\text { Access } \\
\text { Measure(s) }\end{array}$ & $\begin{array}{l}\text { Buffer } \\
\text { Size }\end{array}$ & $\begin{array}{l}\text { Buffer } \\
\text { Shape }\end{array}$ & & & \\
\hline $\begin{array}{l}\text { Commercial } \\
\text { Policy Review } \\
\text { (2010) }\end{array}$ & $\begin{array}{l}\text { Kitchener, } \\
\text { Ontario }\end{array}$ & $\begin{array}{l}\text { Grocery stores } \\
\text { Convenience stores }\end{array}$ & Proximity & $1000 \mathrm{~m}$ & Circular & Neighbourhood & N/A & $\begin{array}{l}\text { Food deserts in } \\
\text { South of Kitchener }\end{array}$ \\
\hline $\begin{array}{l}\text { Community } \\
\text { Planning Studio } \\
\text { (2010) }\end{array}$ & $\begin{array}{l}\text { Prince George's } \\
\text { County, } \\
\text { Maryland }\end{array}$ & $\begin{array}{l}\text { Grocery stores } \\
\text { Convenience store } \\
\text { Liquor store } \\
\text { Farmers' market }\end{array}$ & $\begin{array}{ll}\text { - } & \text { Proximity } \\
\text { - } & \text { Density }\end{array}$ & $800 \mathrm{~m}$ & $\begin{array}{l}\text { Network \& } \\
\text { Circular }\end{array}$ & Block Group & $\begin{array}{ll}\text { - } & \text { Household } \\
\text { income } \\
\text { - } & \text { Car ownership } \\
\text { - } & \text { Population }\end{array}$ & $\begin{array}{l}\text { Three food deserts } \\
\text { in the county }\end{array}$ \\
\hline $\begin{array}{l}\text { Eisenburg \& } \\
\text { Silcott (2010) }\end{array}$ & $\begin{array}{l}\text { Franklin county, } \\
\text { Ohio }\end{array}$ & Grocery stores & Proximity & $\begin{array}{l}400 / 800 / \\
1600 \mathrm{~m}\end{array}$ & Network & Census Tract & $\begin{array}{ll}\text { - } & \text { Household } \\
\text { income } \\
\text { - } & \text { Car ownership } \\
\text { - } & \text { Population }\end{array}$ & $\begin{array}{l}\text { Severe food desert } \\
\text { in east Franklin } \\
\text { county }\end{array}$ \\
\hline $\begin{array}{l}\text { Gordon et al. } \\
\text { (2010) }\end{array}$ & New York City & $\begin{array}{l}\text { Supermarkets } \\
\text { Bodegas } \\
\text { Fast foods }\end{array}$ & $\begin{array}{ll}\text { - } & \text { Proximity } \\
\text { - } & \text { Density }\end{array}$ & $400 \mathrm{~m}$ & Network & Block Group & $\begin{array}{ll}\text { - } & \text { Household } \\
\text { income } \\
\text { - } & \text { Race }\end{array}$ & $\begin{array}{l}\text { Four food deserts } \\
\text { in New York City }\end{array}$ \\
\hline $\begin{array}{l}\text { Kershaw et al. } \\
(2010)\end{array}$ & $\begin{array}{l}\text { Saskatoon, } \\
\text { Saskatchewan }\end{array}$ & $\begin{array}{l}\text { Supermarkets } \\
\text { Fast foods }\end{array}$ & $\begin{array}{ll}\text { - } & \text { Proximity } \\
\text { - } & \text { Density } \\
\text { - } & \text { Variety }\end{array}$ & $1000 \mathrm{~m}$ & Network & DA & Household income & $\begin{array}{l}\text { Primary food } \\
\text { deserts in } \\
\text { Saskatoon's core } \\
\text { and surrounding } \\
\text { neighbourhoods }\end{array}$ \\
\hline $\begin{array}{l}\text { Knight et al. } \\
\text { (2011) }\end{array}$ & $\begin{array}{l}\text { Humboldt Park, } \\
\text { Chicago }\end{array}$ & Grocery stores & Proximity & $500 \mathrm{~m}$ & Circular & Neighborhood & Race & $\begin{array}{l}\text { Food deserts in } \\
\text { south east and } \\
\text { north east of } \\
\text { Humboldt Park }\end{array}$ \\
\hline $\begin{array}{l}\text { Kowaleski-Jones } \\
\text { et al. }(2009)\end{array}$ & $\begin{array}{l}\text { Salt Lake } \\
\text { County, Utah }\end{array}$ & Grocery stores & $\begin{array}{l}\text { - Proximity } \\
\text { - Density }\end{array}$ & $500 \mathrm{~m}$ & Circular & Block Group & Household income & $\begin{array}{l}\text { Different food } \\
\text { desert results } \\
\text { based on employed } \\
\text { definition and } \\
\text { dataset }\end{array}$ \\
\hline
\end{tabular}




\begin{tabular}{|c|c|c|c|c|c|c|c|c|}
\hline \multirow[t]{2}{*}{ Reference (year) } & \multirow[t]{2}{*}{ Study Area } & \multirow{2}{*}{$\begin{array}{c}\text { Food Availability } \\
\text { (Food store Type(s)) }\end{array}$} & \multicolumn{3}{|c|}{ Access Measure(s) } & \multirow{2}{*}{$\begin{array}{c}\text { Data } \\
\text { Aggregation } \\
\text { Level }\end{array}$} & \multirow{2}{*}{$\begin{array}{c}\text { Socioeconomic \& } \\
\text { Demographic } \\
\text { Variables }\end{array}$} & \multirow[t]{2}{*}{ Findings } \\
\hline & & & $\begin{array}{c}\text { Access } \\
\text { Measure(s) }\end{array}$ & $\begin{array}{l}\text { Buffer } \\
\text { Size }\end{array}$ & $\begin{array}{l}\text { Buffer } \\
\text { Shape }\end{array}$ & & & \\
\hline $\begin{array}{l}\text { Larsen \& } \\
\text { Gilliland } \\
(2008)\end{array}$ & London (Ontario & Supermarkets & $\begin{array}{ll}- & \text { Proximity } \\
\text { - } & \text { Density }\end{array}$ & $\begin{array}{l}500 / 1000 \\
\mathrm{~m}\end{array}$ & Network & Census Block & $\begin{array}{ll}\text { - } & \text { Education } \\
\text { - } & \text { Lone parenthood } \\
\text { - } & \text { Unemployment } \\
\text { - } & \text { Low income }\end{array}$ & $\begin{array}{l}\text { Food deserts exist in } \\
\text { the east areas } \\
\text { Of London }\end{array}$ \\
\hline $\begin{array}{l}\text { Leete } \text { et al. } \\
\text { (2011) }\end{array}$ & Portland, Oregon & Grocery stores & $\begin{array}{l}\text { - Proximity } \\
\text { - Density }\end{array}$ & $1000 \mathrm{~m}$ & Circular & Census Block & $\begin{array}{ll}\text { - } & \text { Household } \\
\text { income } \\
\text { - Elderly people } \\
\text { - Car ownership }\end{array}$ & $\begin{array}{l}\text { Different food desert } \\
\text { results based on } \\
\text { employed definition }\end{array}$ \\
\hline $\begin{array}{l}\text { O’Dwyer \& } \\
\text { Coveney } \\
(2006)\end{array}$ & Adelaide LGA & Supermarkets & $\begin{array}{l}\text { - Proximity } \\
\text { - Density }\end{array}$ & $\begin{array}{l}2500 \mathrm{~m} \\
\text { around } \\
\text { each } \\
\text { (LGA) }\end{array}$ & Network & Census Tract & Car ownership & $\begin{array}{l}\text { Food deserts exist in } \\
\text { LGAs }\end{array}$ \\
\hline Parsons (2012) & $\begin{array}{l}\text { Durham, } \\
\text { North } \\
\text { Carolina }\end{array}$ & $\begin{array}{l}\text { Grocery stores } \\
\text { Fast food } \\
\text { Farmers market }\end{array}$ & $\begin{array}{l}\text { - Proximity } \\
\text { - Density }\end{array}$ & $1600 \mathrm{~m}$ & Network & Census Block & $\begin{array}{ll}\text { - } & \text { Household } \\
\text { income } \\
\text { - } \\
\text { - } \\
\text { Elderly people }\end{array}$ & $\begin{array}{l}\text { Food desert } \\
\text { communities } \\
\text { in Durham }\end{array}$ \\
\hline $\begin{array}{l}\text { Ramos et al. } \\
(2008)\end{array}$ & $\begin{array}{l}\text { Northern } \\
\text { Kingston, } \\
\text { Ontario }\end{array}$ & Grocery stores & Proximity & $500 \mathrm{~m}$ & Circular & Neighbourhoods & $\begin{array}{ll}\text { - Household } \\
\text { income } \\
\text { - } \\
\text { Education }\end{array}$ & $\begin{array}{l}\text { Food deserts and } \\
\text { food insecurity exist } \\
\text { in Kingston }\end{array}$ \\
\hline $\begin{array}{l}\text { Rose et al. } \\
\text { (2009) }\end{array}$ & New Orleans & $\begin{array}{l}\text { Supermarkets } \\
\text { Fast foods }\end{array}$ & $\begin{array}{ll}\text { - } & \text { Proximity } \\
\text { - } & \text { Density }\end{array}$ & $\begin{array}{l}1000 / 2000 \\
\mathrm{~m}\end{array}$ & Network & Census Tract & $\begin{array}{l}\text { - Household } \\
\text { income } \\
\text { - } \quad \text { Car ownership }\end{array}$ & $\begin{array}{l}\text { Food desert rates } \\
\text { ranged from } 17 \% \text { to } \\
87 \% \text { based on } \\
\text { operational } \\
\text { definition }\end{array}$ \\
\hline
\end{tabular}




\begin{tabular}{|c|c|c|c|c|c|c|c|c|}
\hline \multirow[t]{2}{*}{ Reference (year) } & \multirow[t]{2}{*}{ Study Area } & \multirow{2}{*}{$\begin{array}{c}\text { Food Availability } \\
\text { (Food store Type(s)) }\end{array}$} & \multicolumn{3}{|c|}{ Access Measure(s) } & \multirow{2}{*}{$\begin{array}{c}\text { Data Aggregation } \\
\text { Level }\end{array}$} & \multirow{2}{*}{$\begin{array}{c}\text { Socioeconomic \& } \\
\text { Demographic } \\
\text { Variables }\end{array}$} & \multirow[t]{2}{*}{ Findings } \\
\hline & & & $\begin{array}{c}\text { Access } \\
\text { Measure(s) }\end{array}$ & $\begin{array}{l}\text { Buffer } \\
\text { Size }\end{array}$ & $\begin{array}{l}\text { Buffer } \\
\text { Shape }\end{array}$ & & & \\
\hline $\begin{array}{l}\text { Russel \& } \\
\text { Heidkamp } \\
\text { (2011) }\end{array}$ & $\begin{array}{l}\text { New Haven, } \\
\text { Connecticut }\end{array}$ & $\begin{array}{l}\text { Supermarkets } \\
\text { Grocery stores }\end{array}$ & Proximity & $\begin{array}{l}400 / 800 / \\
1600 \mathrm{~m}\end{array}$ & Network & Block Group & $\begin{array}{ll}- & \text { Household } \\
\text { income } \\
\text { - } & \text { Car ownership } \\
\text { - } & \text { Poverty level }\end{array}$ & $\begin{array}{l}\text { Severe food desert } \\
\text { in east New Haven }\end{array}$ \\
\hline Schledt (2010) & $\begin{array}{l}\text { Nashville, } \\
\text { Tennessee }\end{array}$ & Grocery stores & Proximity & $500 \mathrm{~m}$ & Circular & Census Block & $\begin{array}{l}\text { - Household } \\
\text { income } \\
\text { - Car ownership }\end{array}$ & $\begin{array}{l}\text { Four food desert in } \\
\text { study area }\end{array}$ \\
\hline $\begin{array}{l}\text { Smoyer-Tomic et } \\
\text { al. (2006) }\end{array}$ & $\begin{array}{l}\text { Edmonton, } \\
\text { Alberta }\end{array}$ & Supermarkets & $\begin{array}{l}\text { - Proximity } \\
\text { - Density }\end{array}$ & $1000 \mathrm{~m}$ & Network & Postal Code & $\begin{array}{ll}\text { - } & \text { Household } \\
\text { income } \\
\text { - Elderly people } \\
\text { - Car ownership }\end{array}$ & $\begin{array}{l}\text { Six food deserts in } \\
\text { suburban areas }\end{array}$ \\
\hline $\begin{array}{l}\text { University of } \\
\text { Washington } \\
\text { (2011) }\end{array}$ & $\begin{array}{l}\text { Puget Sound } \\
\text { region, } \\
\text { Washington }\end{array}$ & Supermarket & Proximity & $800 \mathrm{~m}$ & Network & Census Block & $\begin{array}{l}\text { - Household } \\
\text { income }\end{array}$ & $\begin{array}{l}\text { Food deserts in } \\
\text { suburban areas } \\
\text { except King } \\
\text { county }\end{array}$ \\
\hline Wintle (2010) & $\begin{array}{l}\text { Thunder Bay } \\
\text { region } \\
\text { Northwestern } \\
\text { Ontario }\end{array}$ & $\begin{array}{l}\text { Supermarket } \\
\text { Grocery stores }\end{array}$ & Proximity & $800 \mathrm{~m}$ & Circular & EA and DA & $\begin{array}{l}\text { Accumulation Risk } \\
\text { Factor } \\
\text { - Household } \\
\text { income } \\
\text { - Age }\end{array}$ & $\begin{array}{l}\text { Food deserts exist } \\
\text { in Northwestern } \\
\text { Ontario } \\
\text { communities }\end{array}$ \\
\hline $\begin{array}{l}\text { Yousafzai et al. } \\
\text { (2008) }\end{array}$ & $\begin{array}{l}\text { Region of } \\
\text { waterloo, Ontario }\end{array}$ & $\begin{array}{l}\text { Supermarket } \\
\text { Grocery stores }\end{array}$ & Proximity & $1000 \mathrm{~m}$ & Circular & Census Tract & $\begin{array}{l}\text { - Household } \\
\text { income } \\
\text { - } \text { Population }\end{array}$ & $\begin{array}{l}\text { Food deserts exist } \\
\text { in all four } \\
\text { Waterloo regions }\end{array}$ \\
\hline
\end{tabular}




\section{Chapter 4: Evaluation}

As discussed in previous chapters, the defining of a food desert is vague and researchers have operationalized it based on their interpretation and backgrounds across the studies. They used different methodologies by incorporating food desert elements to measure food access and identify food deserts. In this section I argue that how selecting and utilizing theses elements can influence the validity and results of food desert studies. Moreover, I will discuss how food desert researchers can produce more accurate and valid results based on the lessons from the literature review.

\subsection{Food Availability}

In a given food environment different types of food stores, regardless of their size, supply wide variety of healthy and unhealthy food options. In almost all reviewed studies, supermarkets and grocery stores were used as proxies of healthy food suppliers. They failed to address smaller, locally owned retail stores (e.g., specialty stores and ethnic stores) that may sell produce, and other alternative healthy food sources, such as farmer markets and community gardens. According to Mednath (2012), a "major critique of identifying food deserts is that their measurement can be misleading as areas that are categorized as food deserts that indeed may have more healthy food options than the current classification schema depicts" (Mednath, 2012). The role of small food retailers as sources of healthy food options has been investigated in food desert studies. For example, Short et al. (2007) indicated that food deserts are not located within low-income neighbourhoods in San Francisco as small food retailers are well-dispersed and supply a wide variety of healthy and culturally acceptable foods at relatively low prices. Margheim (n.d) mentioned that grocery stores and supermarkets are not always the only providers of healthy food options in neighbourhoods. He added that ethnic food stores or small 
stores that specialize in meats, seafood, or fruits and vegetables might fill gaps in household food needs. Bitler and Haider (2011) went even further and pointed out that the quality of fresh produce available in small food stores is better when compared with healthy food options in supermarkets. According to the literature review (Table 4.1), three food desert studies (Addy and Pike, 2009; Gordon et al., 2010; Rose et al., 2009) took small food retailers as sources of healthy foods into consideration in identifying food deserts. For instance, Rose et al. (2009) did not consider some neighbourhoods (e.g., Village de L'Est, Treme) as food deserts despite the absence of supermarkets because small food retailers offered needed and basic healthy food options to residents.

Some food desert studies considered farmers' markets as an alternative source of healthy food options in communities. Lakey (2010) stated that "farmers markets play a role in providing lowincome urban communities with affordable, high quality food" (p. 18). In a study in London, Ontario, Larsen and Gilliland (2009) investigated the role of a farmers' market in the Old East neighbourhood where residents are mostly low-income and have no access to supermarkets (food desert). They pointed that the farmers' market improved access to healthy food items such as fresh fruits and vegetables. They added that as the farmers' market supplies a wide variety of healthy food items to residents, the Old East neighbourhood is no longer a food desert. As explained in the previous chapter, Baltimore City's Food Policy \& Johns Hopkins Center (2010) identified 23\% of Baltimore City as food desert areas. However, Traub (2011) questioned the results and showed that six out of the 14 available farmers' markets were located in areas that should therefore not be categorized as a food desert. Based on the literature review (Table 4.1), only two studies (Community Planning Studio, 2010; Parsons, 2012) did not ignore farmers' markets as sources of healthy food options in their measurements. Notably, in the research 
project by the Community Planning Studio (2010) in Prince George's County, Maryland, it was indicated that $44 \%$ of the respondents purchased most of their food items from farmers' markets. According to what I have discussed above, in order to produce more accurate and comprehensive results, other sources of healthy food options (e.g., specialty stores, ethnic stores and farmers' markets) than supermarkets and grocerystores should be incorporated in measuring potential food access and identifying food deserts. The importance of addressing all sources of healthy food options in identifying food deserts will be empirically tested in next chapter.

\subsection{Food Accessibility}

\subsubsection{Accessibility measures: Isochrone vs. Gravity Index}

Researchers have employed GIS methods coupled with mathematical formulations to measure food accessibility and identify food deserts. The isochronic measure is the most common method that has been widely used in measuring food accessibility. Isochrone measures count the number of opportunities (e.g., supermarkets and food outlets) that can be reached within a given travel time, distance, or generalized cost (Wachs and Kumagai, 1973). This generally involves geocoding supermarket stores (or other sources of healthy food options) and then developing an isochrone to determine the proximity and density of food outlets in a given geographical area (Levin, 2011). Based on the major isochronic assumption that neighbourhood residents purchase their healthy food items from the closest supermarket or designated healthy food store, these measures ignore the individual behaviours and weight all food storess equally in a certain area. In order to rectify these shortcomings, some studies suggested creating a gravity index as an alternative measure of accessibility (Adhikari, 2007; Hubley, 2011; Linthicum, 2007). A gravity index combines accessibility with availability. These composite measures use proximity friction modified by a measure of attraction such as sales volume and food store's size (Van Meter et al., 
2010). In other words, gravity index devalues attractions according to their proximity to the point of interest (Linthicum, 2007). Based on the literature review (Table 4.1), only two studies (Apparicio et al., 2007; Knight et al., 2011) incorporated a gravity index to capture both the proximity and attractiveness of healthy food outlets in order to measure food accessibility. However, Levin (2011) pointed out that due to drawbacks in each measures (isochrone and gravity), developing a mixed-methods in measuring food accessibility which is currently absent in food desert literature, seems to be necessary in order to produce more realistic results compared with studies that only used one of them in their measurements.

\subsubsection{Accessibility Parameters: Defining Buffer Size}

In food desert and food access studies, buffer techniques (network and circular) were used to determine the area in which residents have access to healthy food options. Regardless of the employed buffer technique shapes used to capture food outlets in a given area, the distance threshold for walking to a supermarket or grocery store (buffer size) varies across studies (Seliske, 2012). According to the literature review (Table 4.1), the range is from 400 metres (Baltimore City's Food Policy \& Johns Hopkins Center, 2010; Eisenburg and Silcott, 2010; Gordon et al., 2010; Russel and Heidkamp, 2011) to 2000 metres (Rose et al., 2009). In some studies multiple buffer sizes were used to estimate reasonable walking time (Eisenburg and Silcott, 2010; Larsen and Gilliland, 2008; Rose et al., 2009; Russel and Heidkamp, 2011).

Seliske (2012) pointed out that due to the wide variation of buffer sizes used by researchers, making comparisons across studies seems to be difficult. She added that using buffers that are too large or too small may fail to address associations that exist in the food environment. Similarly, Rose et al. (2009) concluded that defining the threshold for a reasonable distance is unique to each area and cannot be generalized to other studies. 


\subsubsection{Comparing Circular and Network Buffers}

Buffering methods have been used in almost all food desert studies to visualize the distance to food stores based on Euclidian and Network distances. Circular and network buffers were the two common buffering methods that were implemented in the Geographic Information System (GIS) by food desert researchers to define the shape of the geographic area and capture food outlets in a given food environment. Circular buffers measure the Euclidean straight line distance (as the crow flies) from a point of interest (e.g., supermarket addresses, center of block groups, and zip postal codes) to create a circular buffer (Selsike, 2012). The circular buffer method has the advantage of being simplistic; it requires less data, time, and expertise and is much easier in terms of implementation in GIS. However, this method is likely to be inaccurate in areas with natural features such as rivers, lakes and cliffs, or built features such as railways, bridges, major highways and suburbs with poor street connectivity. In such cases, areas within the buffer zone may be inaccessible by the residents but still used to calculate food built environment measures (Oliver et al., 2007). Herries (2010) mentioned that 50\% and higher error rates (e.g., creating service area around food stores) are common with the circular buffer method which leads to the overestimation of food access in a certain area.

In order to provide a more realistic measure of a food built environment some scholars moved away from circular buffers to the network buffer method as it accounts for modeling real-world factors such as rate of travel, slope, turn restrictions, one-way streets, and pedestrian-capable segments. Street network buffers are created by following roads extending outwards from a location of interest for a specified distance. Lines are then drawn to connect the endpoints of the road networks, creating an irregular shaped buffer surrounding the point of interest. Street network buffers capture what is actually accessible to a resident when taking the roads to travel 
to and from food outlets (Selsike, 2012). To clarify the issue, Figure 4.1 contrasts circular and street network buffers around a point of interest (e.g., supermarket).

Figure 4.1: Circular Buffer (A) vs. Network Buffer (B)
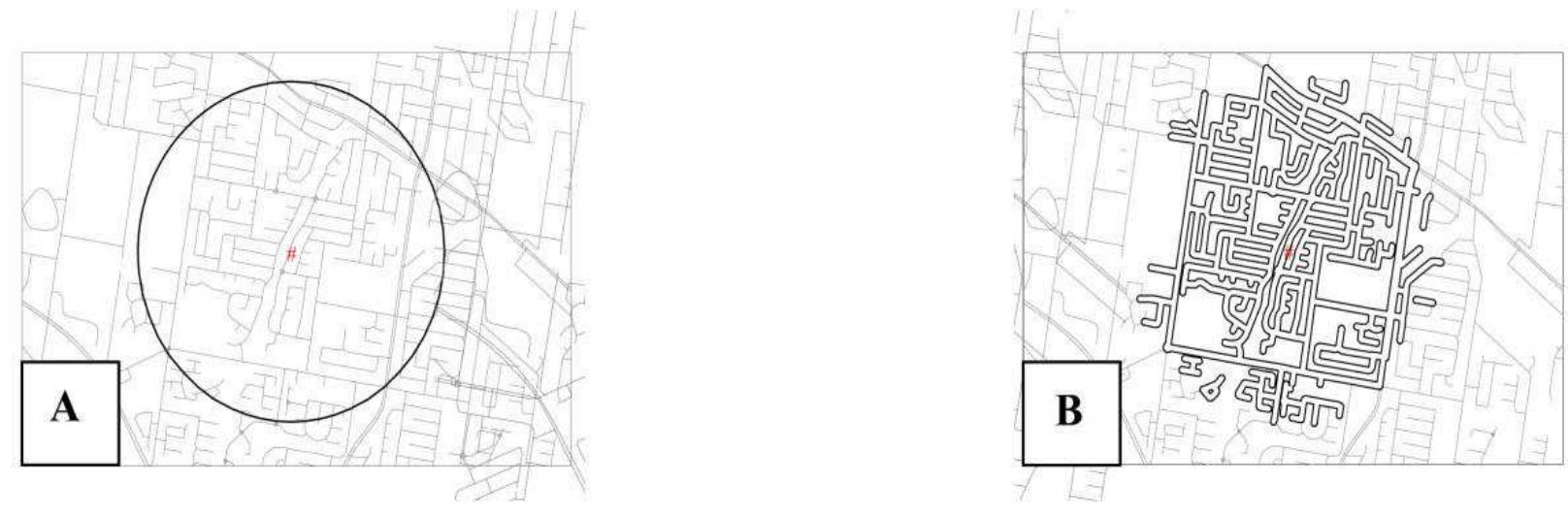

Source: Anthony and Lee (2010, p 13)

In a research project by the Community Planning Studio (2010) in Prince George's County, Maryland, 0.5 mile circular and network buffer methods were drawn around each full-service food outlet (supplier of healthy foods) in order to identify potential food deserts. The concept map results of the two methods were overlaid and the researchers concluded that although inconsistency exists between the captured area and food outlets in each method, the differences are not considerable in Prince George's County neighbourhoods. In contrast, some studies showed that employing network or circular buffer methods has a significant impact on the results of assessing a given built environment (Oliver et al., 2007; Hoch, 2008).

According to what I have discussed above, in order to provide more realistic measurements of adequate access and capture the food environment, using the network buffer method is recommended in identifying food deserts despite the fact that it does not account for traffic and 
weather situations. The importance of employing the network buffer method in identifying food deserts will be empirically tested in next chapter.

\subsection{Geographic Unit: Data Aggregation}

In food desert studies, spatial accessibility is based on the measurement of proximity between residents and food outlets. Due to some reasons, such as security, confidentiality and dissemination issues, populations are often aggregated into areal units (e.g., census tract, neighbourhood). Researchers that calculate distances based on aggregated units should deal with the difficulties that result from the ecological fallacy which makes inferences from higher to lower geographical units (Hewko et al., 2002; Robinson, 1950). The ecological fallacy is the mistake of drawing conclusions from an aggregated level to a smaller spatial unit (Luberichs and Wachowiak, 2010). According to Luo et al. (2010) spatial aggregation errors arise due to the agglomeration of residents and georeferenced observations into larger areal units. When data are aggregated spatially, a smoothing or generalization process causes aggregated data to include less detailed information (Wong and $\mathrm{Wu}, 1996$ ). A growing body of literature emphasised that failing to consider aggregation errors in spatial access measurements impacts on the accuracy and comparability of results across studies (e.g., Apparicio et al., 2008; Hewko et al., 2002; Sparks et al., 2011).

In order to minimize aggregation errors, Apparicio et al. (2008) recommended using smaller spatial units entirely contained by the census tracts, such as dissemination areas, census blocks, or postal codes, which account for the spatial distribution of the population inside the census tract. Similarly, Hewko et al. (2002) suggested that instead of measuring distance from the unweighted geometric centroid of a neighbourhood, distance can be calculated from the population-weighted mean centre of the finer spatial units within a neighbourhood boundary. 
According to the literature review, a few studies tried to minimize or eliminate aggregation errors by calculating food accessibility for a particular neighbourhood or census tract based on a population-weighted average distance of smaller spatial units such as postal codes and block level within larger spatial units (e.g., Apparicio et al., 2007; Leete et al., 2011; Smoyer-Tomic et al., 2006).

\subsection{Socioeconomic and Demographic Variables}

Although food desert concept literally refers to absence of healthy food stores in a given area, studies of food deserts more commonly investigate the association between access to healthy and affordable food options and socioeconomically advantaged and disadvantaged areas (Beaulac et al., 2009). Some researchers believe that suburban areas with well-off residents should not be classified as food deserts because, although they do not have geographic access to healthy food stores in the vicinity of their neighbourhood, they can afford the cost of transportation to obtain healthy food options (e.g., Laresn and Gilliland, 2008; Rose et al., 2009). In order to define which neighbourhoods are disadvantaged regardless of the location in inner-city or suburban areas, food desert researchers used one or a combination of socioeconomic variables such as income, employment rate, education, household structure, and immigrant status. Leete et al. (2011) suggested that demographic variables (e.g., age and single-parent families) that impact physical mobility should also be incorporated in defining disadvantaged areas. It should be noted that, although in most food desert studies the evidence of a relationship between socioeconomic variables and access to healthy foods has been found, the findings of some researchers indicated no significant relationship between income and adequate food access (Apparacio et al., 2007; Bitler and Haider, 2011; Smoyer-Tomic et al., 2006). 


\section{Summary of Evaluation}

In this chapter, critical and major food access and food desert elements and their importance were investigated deeply. After reviewing the literature, it is indicated that almost all studies failed to consider one or some of the food access and food desert elements by ignoring them or by utilizing the elements improperly in their methodology. However, in some Canadian studies (e.g., Apparicio et al., 2007; Larsen and Gilliland, 2007; Smoyer-Tomic et al., 2006) in which the authors mainly focused on measuring food access to identify food deserts, most of the food desert elements have been incorporated and used precisely. 


\section{Chapter 5: Data and Methodology}

As mentioned in Chapter 1, one of the primary objectives of this study is to introduce alternative methodologies based on utilizing food desert elements that produce more comprehensive and accurate results. Throughout this study, the conceptual definition of a food desert is "a disadvantaged area of a city with relatively poor access to [sources of] healthy and affordable food [options]". This conceptual definition was derived from Larsen and Gilliland's (2008) food desert study in the City of London, Ontario. In this chapter, I will operationalize the major elements of this conceptual definition such as "disadvantaged areas", based onpast food desert studies (e.g., Chen, 2011; Martin prosperity Institute, 2010) in the City of Toronto and "poor access" and "sources of healthy and affordable food options" based on the first two recommendations of this study in the previous chapter. Then the operationalized definition will be tested empirically in one of the Toronto neighbourhoods to compare the results with other food desert studies in the same area. It should be noted that the reason for the comparison is not to negate the other researchers' efforts but to contribute producing more comprehensive and precise results.

\subsection{Study Area}

In order to choose the disadvantaged neighbourhoods in the City of Toronto to operationalize the food desert definition in this study, I will rely on both the Chen (2011) and The City of Toronto Neighbourhood Action Plan (2008) studies. Chen (2011) used socioeconomic variables such as income, immigration status, car ownership, education, and employment to classify disadvantaged neighbourhoods in the City of Toronto. In another study, The City of Toronto Neighbourhood Action Plan (2008) designated 13 Priority Areas based on socioeconomic and demographic factors (e.g., population, employment, income, and vulnerable groups) which were extracted 
from the Canada Census 2006 and the city's 2007 Employment Survey. The results of both studies in identifying disadvantaged neighbourhoods in the City of Toronto were very consistent (see Appendix A). For instance, the Englemount-Lawrence area is one of the Toronto neighbourhoods which were classified as disadvantaged neighbourhoods in both studies. Moreover, in Toronto food desert studies (e.g., Chen, 2011; Martin prosperity Institute, 2010) a large portion of this disadvantaged neighbourhood was identified as a food desert. In this study, the Englemount-Lawrence neighbourhood was chosen as the study area to be tested as a food desert neighborhood based on the developed operational definition of food desert. The geographic location of the Englemount-Lawrence neighbourhood is shown in Figure 5.1.

Figure 5.1: Geographic Location of Englemount-Lawrence Neighbourhood

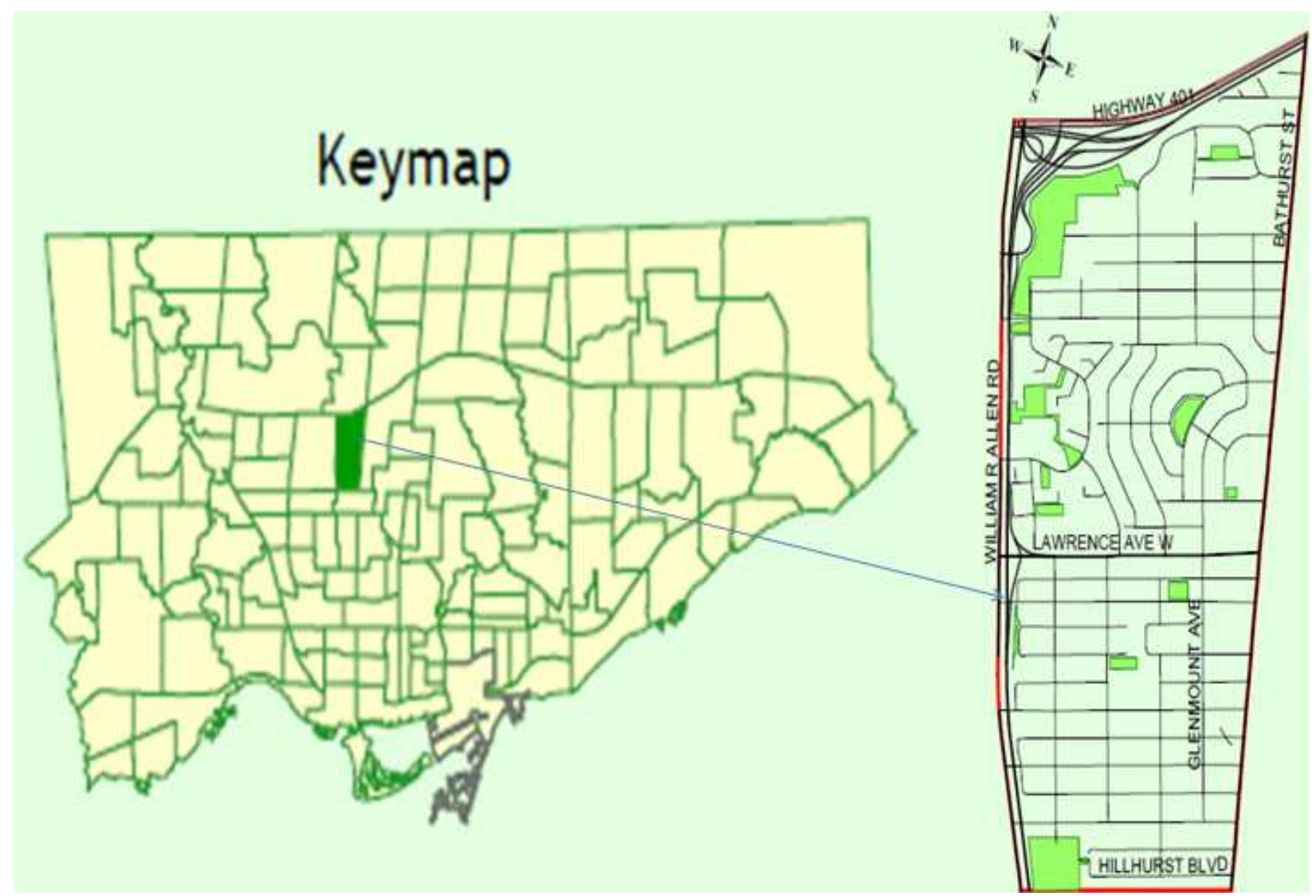

Source: The City of Toronto (2008) 
The Canada Census 2006 provided a socio-demographic profile of the neighborhood. The total population of the study area is 21,115 . There is racial and ethnic diversity in the neighborhood. Twenty five percent of the population identifies as Jewish and 12\% identifies as Filipino, the top two ethnic groups in the neighbourhood. Even in this relatively small neighbourhood, a significant amount of economic differentiation is evident. In particular, populations in the southern part of the neighborhood tend to have significantly higher incomes than populations in the northern area. The median household income before-tax is Can $\$ 45,060$ in the neighbourhood.

\subsection{Measuring Food Availability}

In most food desert studies in the City of Toronto (e.g., Chen, 2011; Lister, 2007; Martin prosperity Institute, 2010) the availability of healthy and affordable food options was approximated using the supermarkets and grocery stores. However, Ver ploeg (2009) argued that a focus only on supermarkets and grocery stores is likely to underestimate the availability of healthy food options since some of these healthy foods are also available at other food stores such as ethnic stores, specialty stores and farmers' markets. In this study, I defined access to healthy and affordable food through availability of the following food stores based on North American Industry Classification System (NAICS):

1. Supermarkets and grocery stores, which are primarily engaged in retailing a general line of food, such as canned, dry and frozen foods; fresh fruits and vegetables; fresh and prepared meats; fish, poultry, dairy products, baked products and snack foods.

2. Specialty food stores, which primarily engaged in retailing specialized lines of food products (e.g., meat, fish and seafood, fruit and vegetable markets).

It should be noted that for the first classification (supermarkets and grocery stores), based on Chen's (2011) food desert study in the Greater Toronto Area (GTA), I only included discount 
supermarket chains (No Frills, Food Basics, and Price Chopper) which provide healthy food options at competitive prices. A specialty store was defined as a food store which sells at least one of the items such as meat, fish and seafood, fruit and vegetable markets, according to the NAICS classification. Bakeries are not included in this study, as they do not sell healthy items according to the USDA definition for healthy food items. Moreover, due to the lack of a clear definition for ethnic stores as one of the important sources of healthy food options, this study adopted and modified the definition, from Crouch's (2011) study, as any type of non-chain grocery store or supermarket which sells food items that are distinctly cultural, often catering to specific segments of the immigrant population, and whose signage is in a language other than English.

\subsubsection{Data Preparation for Food Stores}

As the study area was the Englemount-Lawrence neighbourhood, it was essential to the analysis that, in order to minimize edge effects (failing to address nearby food stores outside the neighbourhood boundary that would likely cause inaccuracies in measuring food availability), food stores located 1000 metres beyond the neighbourhood boundaries were also included as possible sources of healthy food options for residents of Englemount-Lawrence neighbourhood. Food store (discount supermarkets, specialty stores, and ethnic stores) addresses and signs were gathered through field survey and on-site direct observation as the study area was small (see Appendix B). All food store addresses were geocoded within GIS (ArcGIS 10, ESRI). Geocoding is the process of matching raw address information (e.g., household, food stores) with a digital spatial dataset that includes all addresses within the area of interest mapped to latitude and longitude coordinates (Thornton et al., 2011). 


\subsection{Measuring Food Accessibility}

Determining the threshold for poor access to food stores that provide healthy food options is one of the essential elements of the operational definition of food deserts developed for this study. Poor access for neighbourhood residents in this study is defined as a location outside a reasonable walking distance to a food store. In almost all Canadian studies (e.g., Apparicio et al., 2007; Larsen and Gilliland, 2007; Smoyer-Tomic et al., 2006) and especially those in the City of Toronto, a distance of 1000 metres was determined as a reasonable walking distance (e.g., Chen, 2011; Martin prosperity Institute, 2010). Therefore, in order to compare the results with Toronto studies, a 1000 metre distance was used as a reasonable walking distance for neighborhood residents to reach food stores. In order to measure accessibility, ArcGIS 10.0 and the Network Analysis extension was used to create a 'service area' of 1000 metres around each food store based on CanMap Streetfiles from DMTI (Desktop Mapping Technologies Incorporated).

\subsection{Identifying Food Deserts}

As the study area (Englemount-Lawrence neighbourhood) has already been classified as a disadvantaged neighbourhood, therefore, areas outside the food store (discount supermarket chains, ethnic stores, and specialty stores) service area will be identified as food deserts in this study. 


\section{Chapter 6: Results}

As I pointed out in previous chapters, different ways of operationalizing the food desert definition can influence food desert results. One of the primary objectives of this study is to operationalize a food desert definition which produces more comprehensive and accurate results. In order to clarify the discrepancies in food desert analysis, the results based on the developed operational definition of food desert in this study will be compared with Chen's (2011) operational definition for Englemount-Lawrence neighbourhood. The developed operational definitions of a food desert in this study and Chen (2011) study for the Englemount-Lawrence neighbourhood are as follows:

- Chen (2011): Disadvantaged areas where residents are located outside a 1000 metre circular buffer zone (service area) of discount supermarkets.

- This study: Disadvantaged areas where residents are located outside a 1000 metre network buffer zone (service area) of discount supermarkets, ethnic stores and specialty stores.

It should be noted that, in this study, disadvantaged areas were operationalized based on Chen's (2011) study for the sake of brevity and comparability. By comparing the both operational definitions of food desert, it is conspicuous that there are slight differences in terms of measuring food availability and accessibility. In this chapter, the influence of these differences in identifying food desert areas in Englemount-Lawrence neighbourhood will be investigated by modifying step-by-step Chen's (2011) operational definition to produce the developed operational definition of a food desert in this study.

The map of food desert results based on Chen's (2011) operational definition with respect to edge effect is shown in Figure 6.1. 
Figure 6.1: Map of Food Deserts in Study Area Based on Chen (2011) Definition

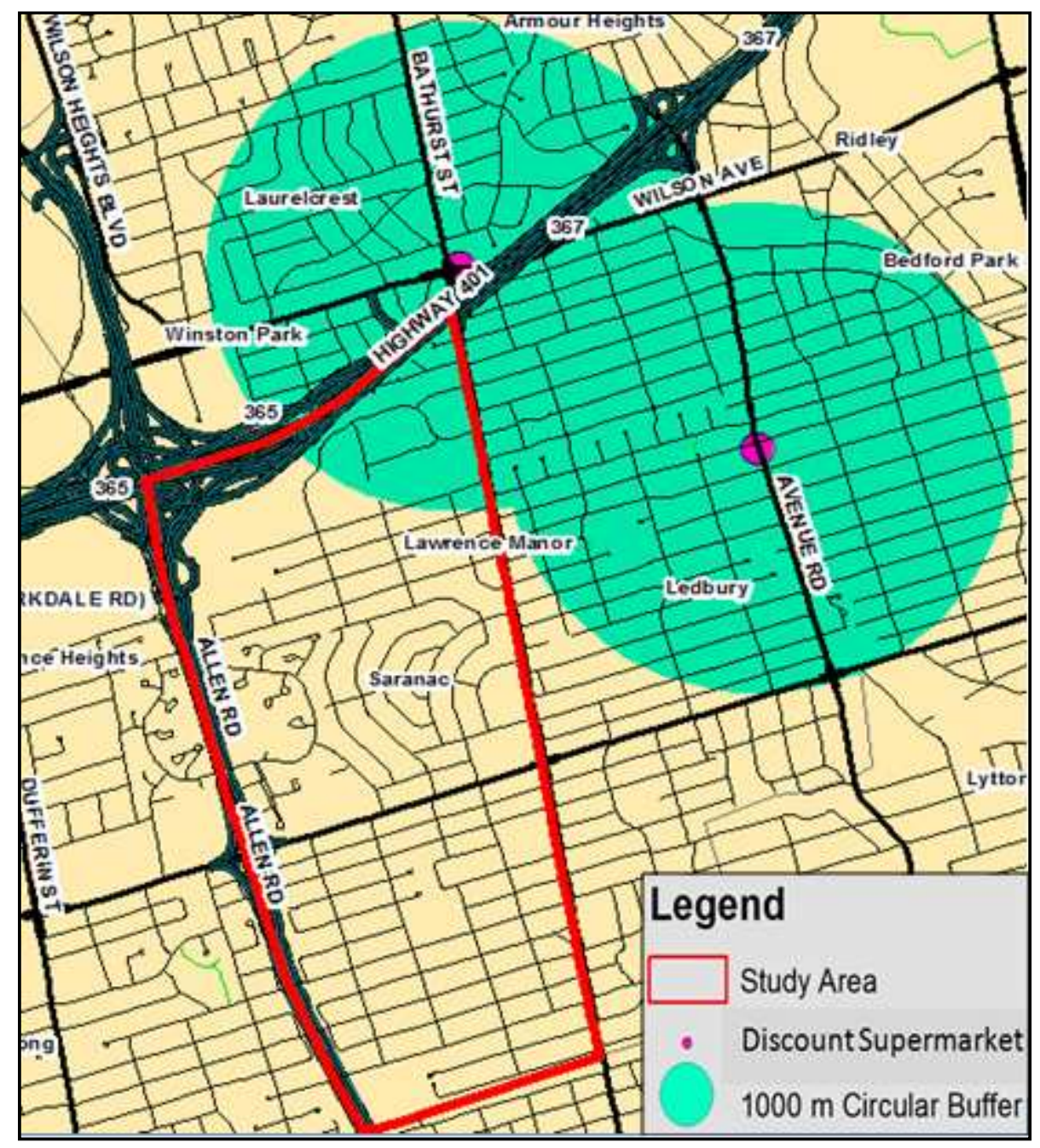

According to Chen's (2011) food desert analysis (Figure 6.1), a large portion of the EnglemountLawrence neighbourhood area was identified as a food desert. In the next section, I will investigate whether existent differences in food availability and accessibility influence food desert results in the study area.

\subsection{Difference in Measuring Food Availability}

In Chen's (2011) operational definition of a food desert, discount supermarket chains were assumed to be the only providers of healthy and affordable food options. However, in this study, 
not only discount supermarket chains but also ethnic stores and specialty stores were assumed to be providers of healthy and affordable food options for residents of Englemount-Lawrence neighbourhood. The first step in modifying Chen's (2011) operational definition to the one developed in this study is shown on the food desert map area in Figure 6.2. It should be noted that the developed operationalization of food accessibility was kept constant in this section for the sake of simplifying the modifying procedure to reach the final food desert results in the Englemount-Lawrence neighbourhood.

Figure 6.2: Food Deserts: Based on Study Operetionalizing of Food Availability

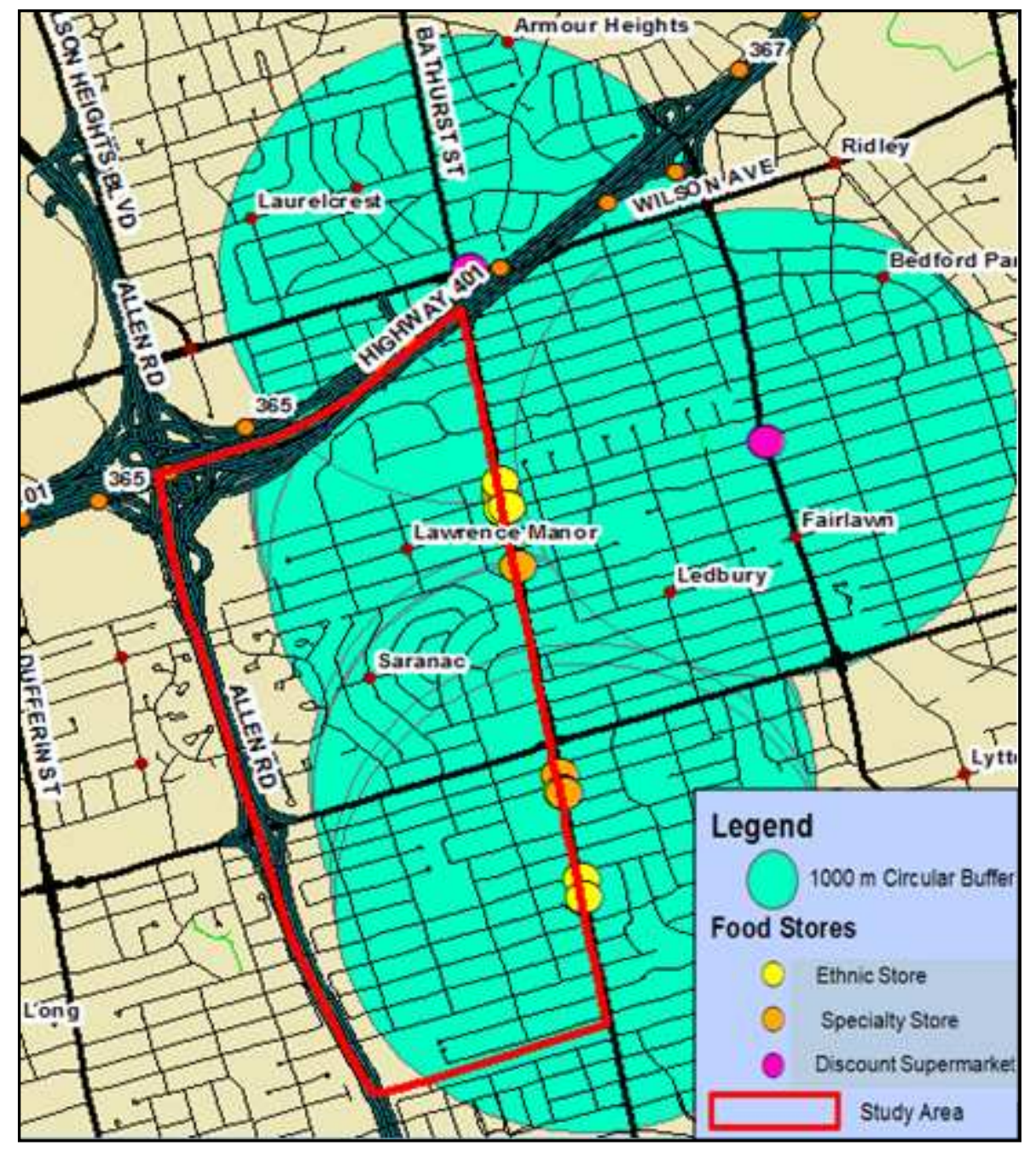


According to Figure 6.2, and in contrast with Chen (2011), the revised food desert map (Figure 6.1) indicated that only a small portion of the study area is identified as food desert due to the contributions of other food stores such as ethnic stores and specialty stores in providing healthy and affordable food options. Moreover, ethnic stores in the study area not only supply healthy and affordable food options but also provide culturally-accepted foods for the residents of other ethnicities. For example, according to The City of Toronto (2008), Jewish and Filipino ethnic groups are the pre-dominant ethnicities in Englemount-Lawrence neighbourhood. Subsequently, out of seven identified ethnic stores in the study area, five of them are Jewish ethnic stores and the other two are Filipino ethnic stores (see Appendix B).

\subsection{Difference in Measuring Food Accessibility}

In Chen's (2011) operational definition of a food desert, a circular buffer method (based on Euclidean distance) was used to create the service area around each discount supermarket and subsequently identify adequate access to healthy and affordable food options for neighbourhood residents. In contrast, in order to operationalize food accessibility in this study, the network buffer method was used to create the service area around each discount supermarket. The second step in modifying Chen's (2011) operational definition is shown in Figure 6.3. It should be noted that the developed operationalizing of food availability by this study was kept constant in this section for the sake of comparison and simplifying the modifying procedure to reach the final food desert results in the Englemount-Lawrence neighbourhood. 
Figure 6.3: Food Deserts: Chen (2011) vs. Study Operetionalizing of Food Accessibility

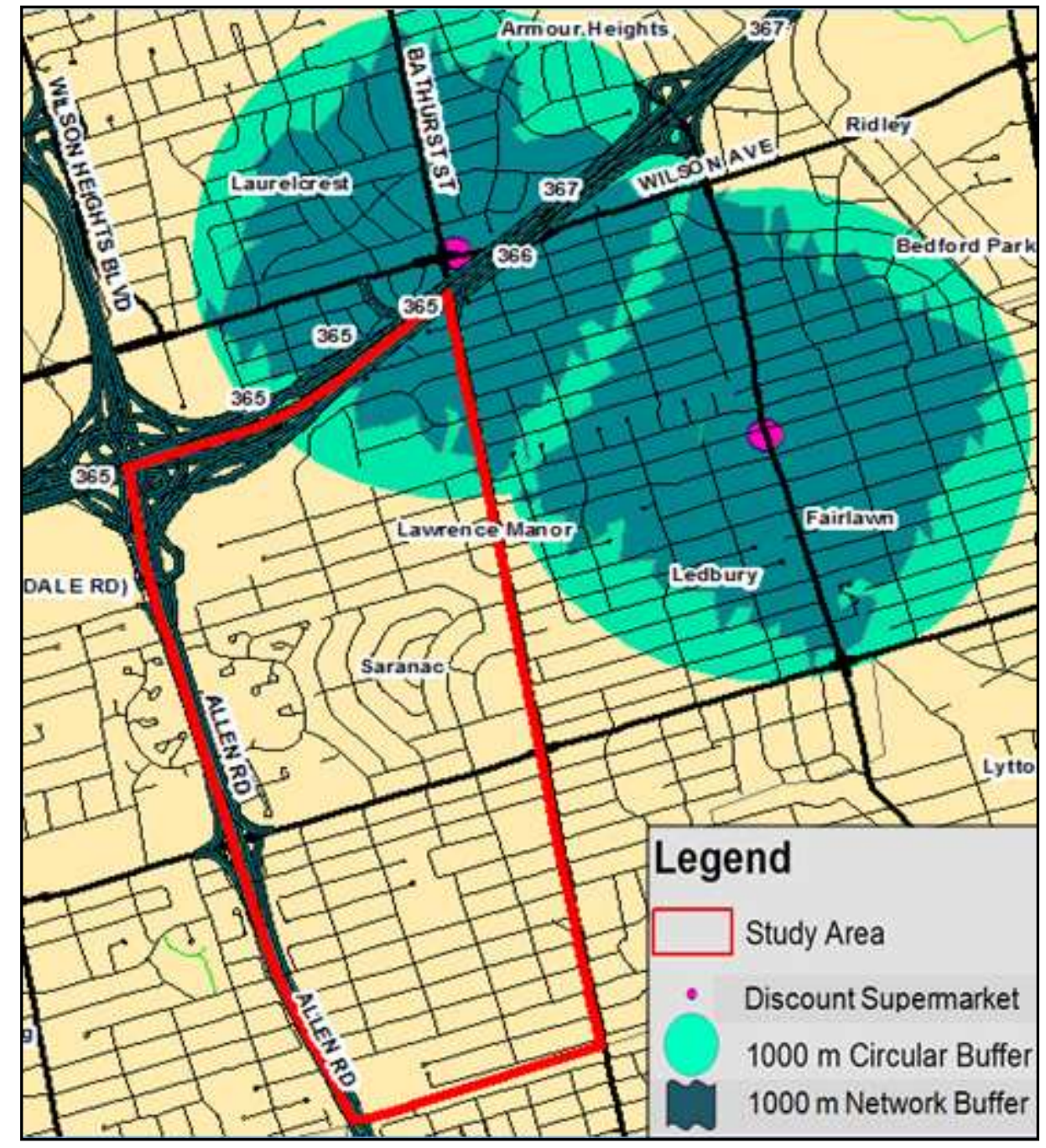

According to Figure 6.3, there are differences between service areas created by each buffer method (areas in blue). It can be concluded that using a circular buffer method overestimates the actual service area for each discount supermarket in the study area. In other words, the service areas overestimated by circular buffers are not identified as food deserts based on the developed operational definition of food desert in this study. 


\subsection{Identifying Food Deserts}

In order to produce more comprehensive and accurate results, both differences in measuring food availability and accessibility (step one and two) from Chen's (2011) study will be incorporated to reach the final developed operational definition of food desert in this study. The final map of food desert results for the Englemount-Lawrence neighbourhood based on the developed methodology is shown in Figure 6.4.

Figure 6.4: Food Deserts in the Englemount-Lawrence Neighbourhood

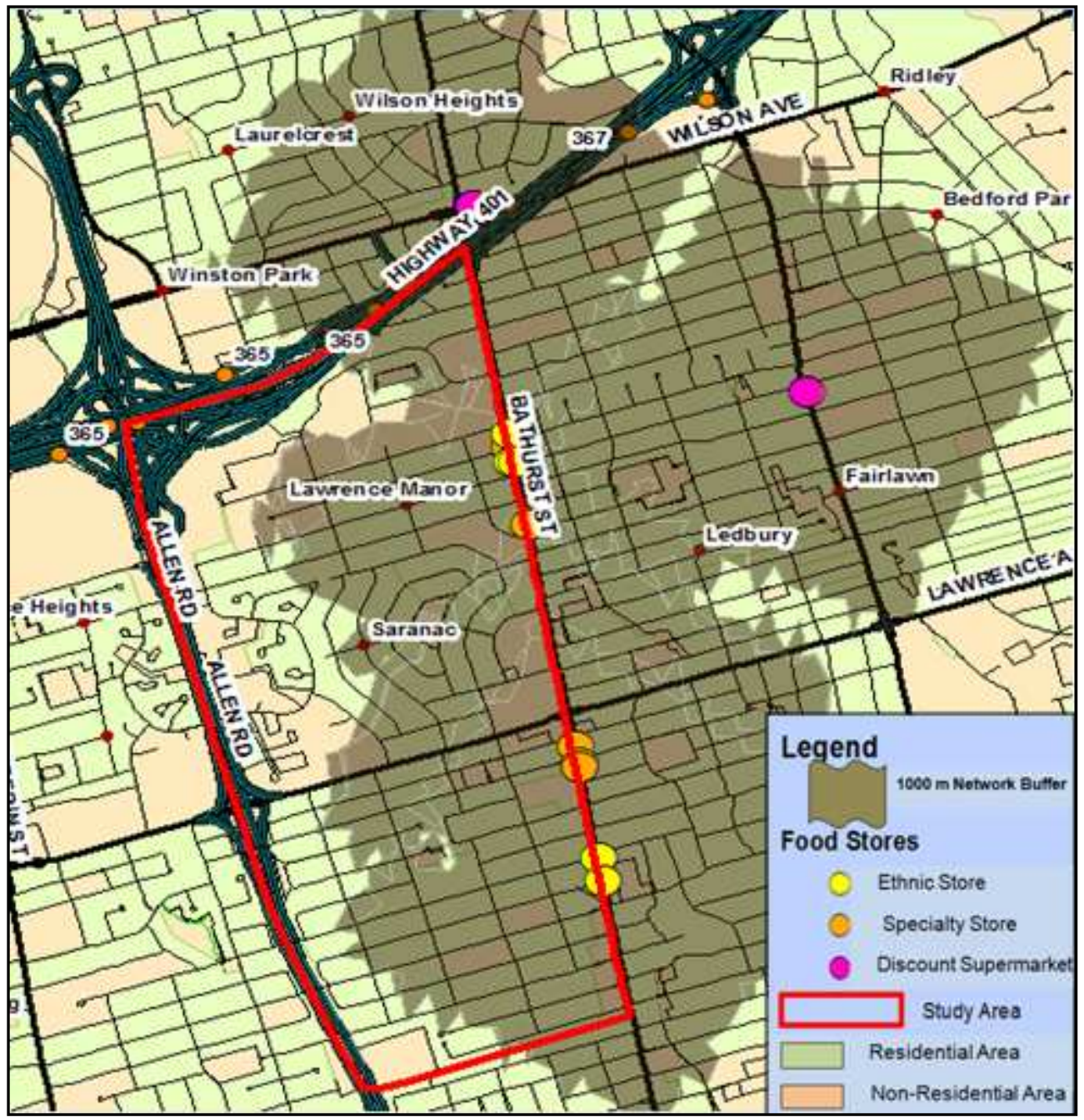




\section{Chapter 7: Discussion}

Exploring food access issues and identifying food deserts in the Englemount-Lawrence neighbourhood was done using alternative methodologies. The findings of this study showed that, depending on the operational definition of food desert (e.g., measuring food accessibility and food availability), the results can be altered widely in the study area. In order to clarify where these inconsistencies in identifying food deserts come from, I compared the results derived from both Chen's study (2011) and the developed methodology in this study. According to Chen's (2011) analysis, a large portion of the study area was identified as a food desert (Figure 6.1). In contrast, based on the developed methodology in this study, only a small portion of the Englemount-Lawrence neighbourhood was identified as a food desert mostly in nonresidential areas (Figure 6.4). The results from Chen's (2011) methodology compared with the developed methodology in this study, indicated that different ways of measuring food availability and food accessibility produced inconsistencies in identifying food desert areas in the Englemount-Lawrence neighbourhood.

\subsection{Measuring Food Availability}

In Chen's (2011) study, only discount supermarket chains were addressed as sources of healthy and affordable food options. However, researchers argue that by ignoring alternative sources of healthy and affordable food options such as specialty stores, ethnic stores and farmers' markets, this limitation is likely to overestimate the food desert areas (Bodor et al., 2008; Neckerman et al., 2009; Ver Ploeg, 2009). In this study, not only the discount supermarket chains but also specialty stores and ethnic stores were included to depict a more complete picture of the food environments in the Englemount-Lawrence neighbourhood. The findings of this study are consistent with the results of Rose et al. (2009) and Short et al. (2007) which indicated that an 
area cannot be identified as a food desert based on the absence of supermarket and grocery stores when alternative sources of healthy and affordable food options are well-dispersed in the given area. In contrast, in a study by Nasr et al. (2011) in the three neighbourhoods (Dixon-Islington, Scarborough village-Cliffcrest, and Thorncliffe-Flemingdon in the City of Toronto), the results indicated that ethnic stores and specialty stores in those three neighbourhoods cannot offset the relative lack of supermarkets in providing healthy and affordable food options because they are small in number and supply fewer healthy food options such as grains, milk, and meat products. However, the results of this study showed that ethnic stores and specialty stores not only enhance geographic access to healthy and affordable food options but also provide ethnic foods that meet cultural and religious preferences for immigrants such as Jewish and Filipino ethnicities in the Englemount-Lawrence neighbourhood. Koc and Welsh (2002) pointed out that culturallyaccepted food by specialty stores and ethnic stores can improve food security among immigrants in the Toronto neighbourhoods.

\subsection{Measuring Food Accessibility: Buffering Method}

In Chen's (2011) study, a 1000 metre circular buffer was employed to create the service area around each discount supermarket chain to define adequate access for residents as living within reasonable walking distance in the study area (Figure 6.1). In contrast, other researchers criticized the circular buffer method and suggested that it does not provide information about the street network system and it underestimates the distance that residents would actually need to walk to reach food stores (e.g., Blackston, 2012; Winkler, 2008). In other words, by using this method, a portion of the service area around each food store, which was defined as area of adequate access for residents to obtain healthy and affordable food options, is really a food desert. In order to minimize the error and produce more realistic results, a network buffer was 
employed to create a service area based on street network system. The difference in creating service areas based on both buffer methods is shown in the study area (Figure 6.3). The mapping analysis results indicated that a circular buffer overestimated the service area around each food store. The findings are consistent with findings by Herries (2010), Oliver (2007), and Selsike (2012). In contrast, a study by the Community Planning Studio (2010) in the Prince George's County, Maryland, indicated that there is no significant difference between service areas created by each buffer method. It can be concluded that, in areas with more natural and built features in which streets tended to follow a less regular and gridded pattern, the use of a network buffer can significantly alter the results (Neckerman, 2009).

\subsection{Limitations of This Study}

This study has several limitations that should be noted. The primary limitation is that I only measured "potential access" and measuring "realized access" was not done in this study. Potential access identified food stores where residents could possibly shop, while realized access shows where residents actually shop (Sharkey and Horel, 2009; Ver Ploeg, 2009). Some residents may shop on their way home from work, school, or other activities. Another limitation is that accessibility to food stores by walking was only measured according to a pre-defined reasonable distance and information on other modes of travel or access to public transit was not taken into account. For example, if residents have access to low-cost transportation, local affordability may not influence actual shopping decisions (Dunn et al., 2011). Lastly, I did not conduct an in-store survey on devoted shelf space to healthy and 'junk' food options by food store type. This measure could help to understand consumer behavior and whether higher proportions of unhealthy food options in or near food stores lead residents to make fewer healthy and more unhealthy choices (Community Planning Studio, 2010). 


\subsection{Implication of the Results}

\subsubsection{Methodological Implications}

In previous chapters, I pointed out that the food desert concept is debated among scholars. Because of the different ways of operationalizing and the diverse methodologies used in identifying food deserts, some researchers have doubts about developing a methodology which can produce more accurate and realistic results. In order to advance the analysis, I compared the advantages and drawbacks of alternative methodologies based on common food desert elements (e.g., availability, accessibility, data aggregation units, and socioeconomic and demographic variables) across the food desert literature. Moreover, the mapping analysis results, employing alternative measurements of food deserts in one Toronto neighbourhood, were demonstrated spatially in this study. Scholars and students who plan to conduct research on food access and food desert issues can take advantage of the comparative results of this study in order to develop a more appropriate methodology to measure food access and identify food deserts.

\subsubsection{Practical Implications}

As awareness of the link between the food environment, health-related and environmental consequences grows, practitioners and policy-makers need a better understanding of food deserts in urban neighbourhoods. They are often concerned and skeptical about the accuracy and validity of information that should to be taken into account in guiding policy interventions, especially regarding complex issues that have achieved less consensus among researchers. In this study, I indicated that properly selecting and utilizing general food desert elements can minimize the methodological errors and improve the comparability and generalizability of the results across studies. The findings of this study can be used as an assessment tool for policy-makers to understand the precision and accuracy of findings based on the elements employed to measure 
food access and identify food deserts in a given area. Therefore, incorporating the results from the most appropriate methodology in designing interventions can provide a framework for policy-makers to find concrete solutions to real world problems.

\subsection{Recommendations for Future Research}

A growing body of literature has relied more heavily on quantitative approaches. Even advanced mathematical formulations and sophisticated quantitative measures cannot capture the complexity of personal preferences and individual decision making. Surveys of individuals and households using qualitative methods (e.g., participatory approaches and focus groups) and undertaking interviews are highly recommended for future studies in order to acquire in-depth data on food shopping behaviour, consumption behaviour, and cultural matters. The central questions are: What are the types of food stores at which major shopping is done, the distance to the food stores and what are the time and costs required to reach them, and the modes of transportation used to reach those food stores.

Although ethnic stores and specialty stores can be alternative sources of healthy food options, they may target specific segments of the local population. Further research is required to understand whether residents of other ethnicities face social and cultural barriers to purchase healthy food options from these food stores.

In many studies, household income and distance are assumed to be the significant barriers in access to healthy food options. A more extensive set of explanatory variables (e.g., age, education, household structure, single parent families, mobility tools, occupation, and urban form) is needed for future research in order to measure food access and identify food deserts. 


\section{Appendices}

Appendix A: Disadvantaged Areas in the city of Toronto

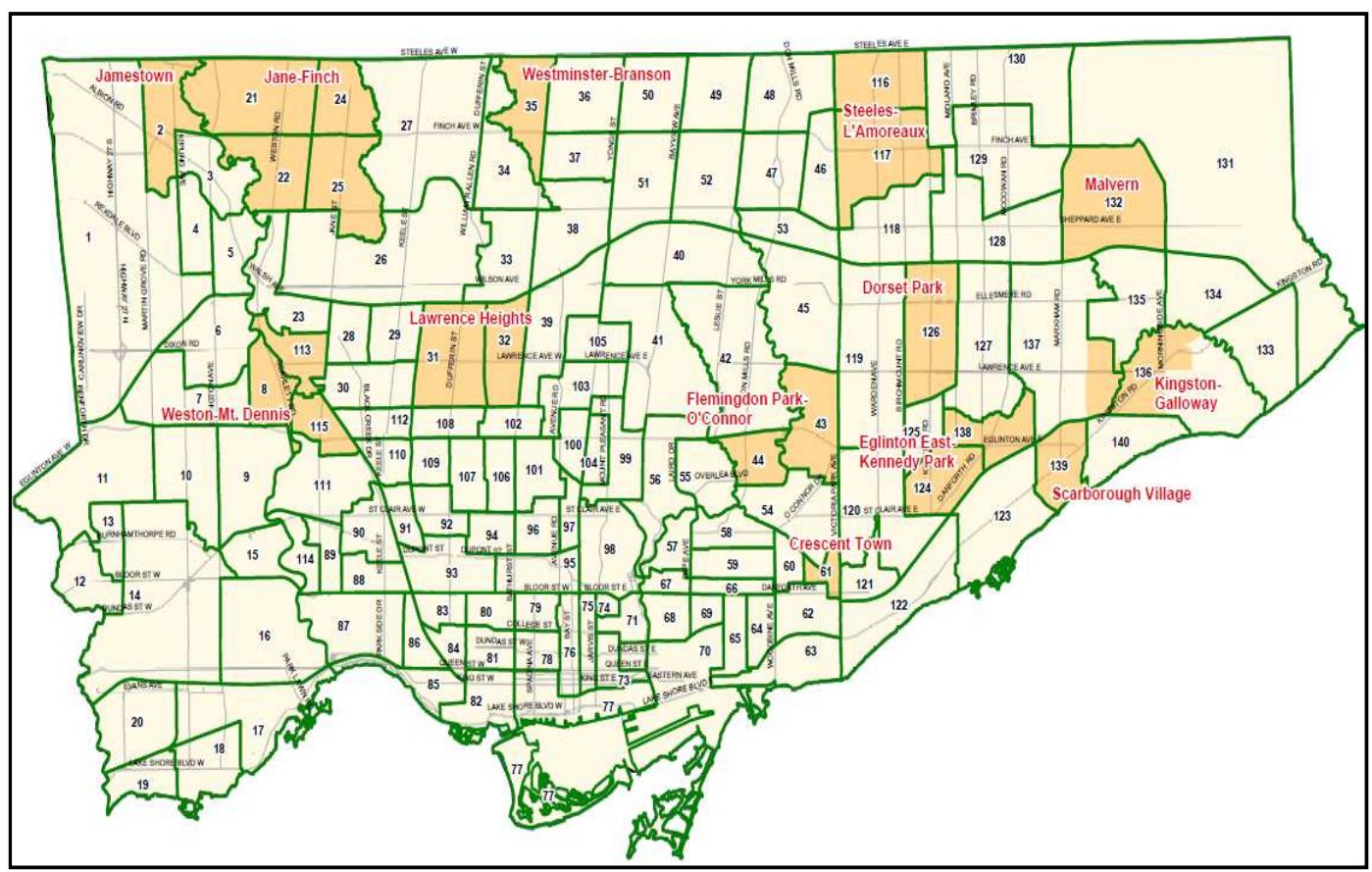

Source: Cityof Toronto (2009)

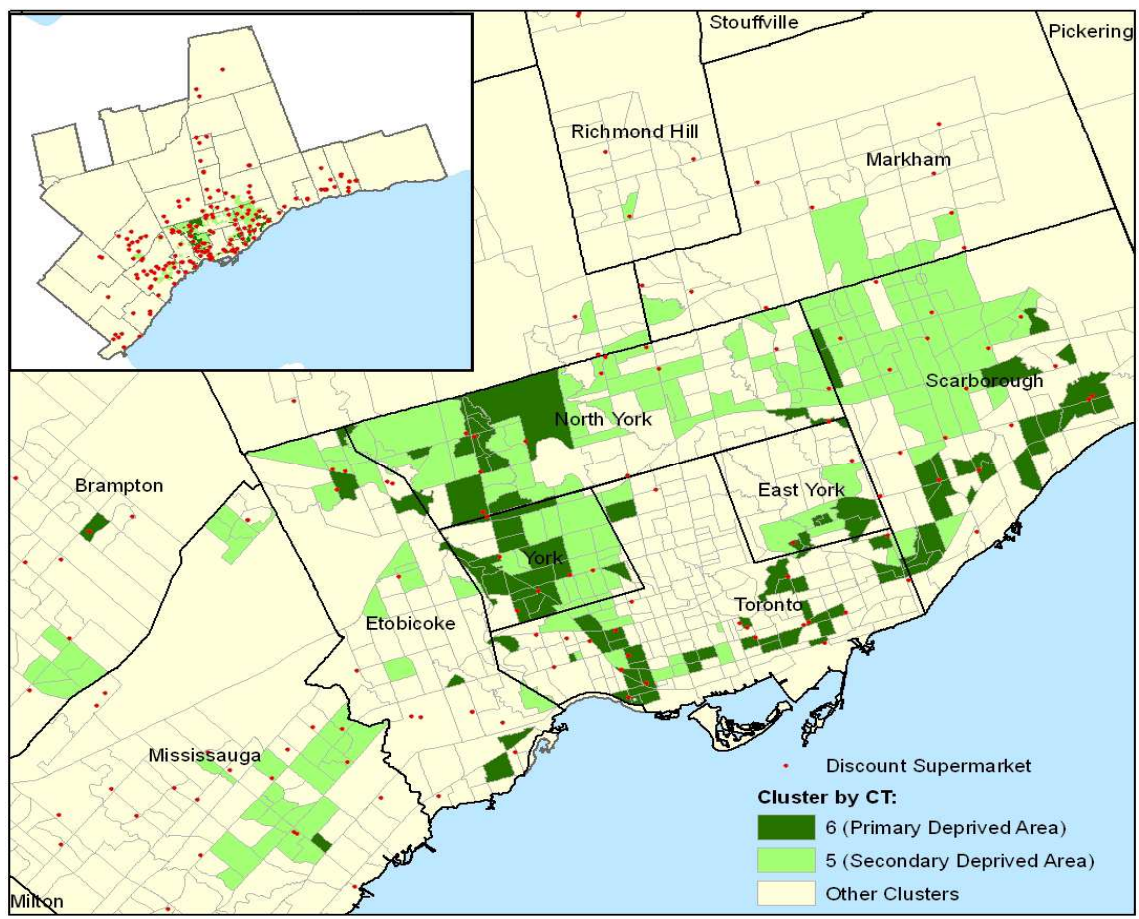

Source: Chen (2011) 
Appendix B: Ethnic Stores and Specialty Stores in the Englemount-Lawrence Neighbourhood
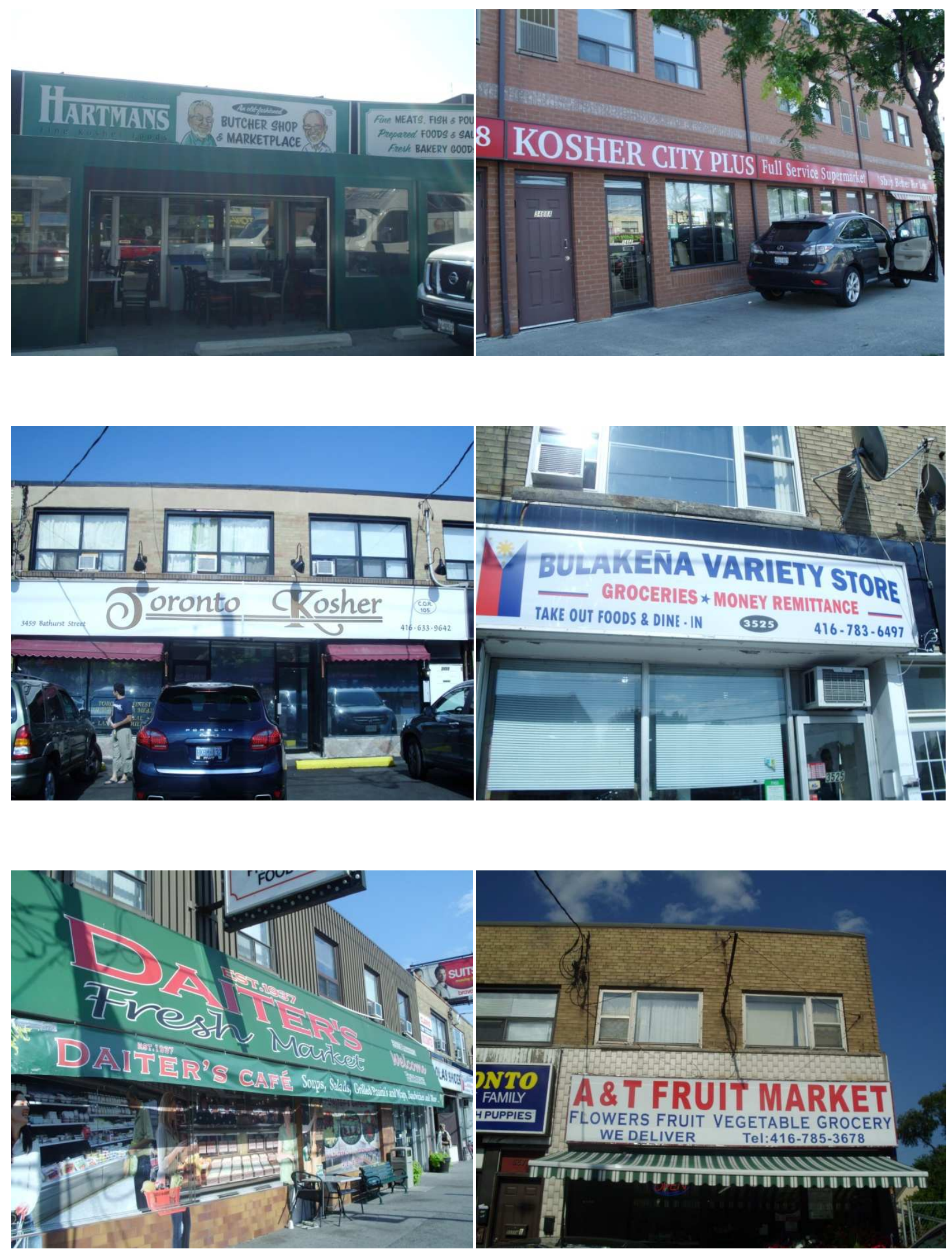

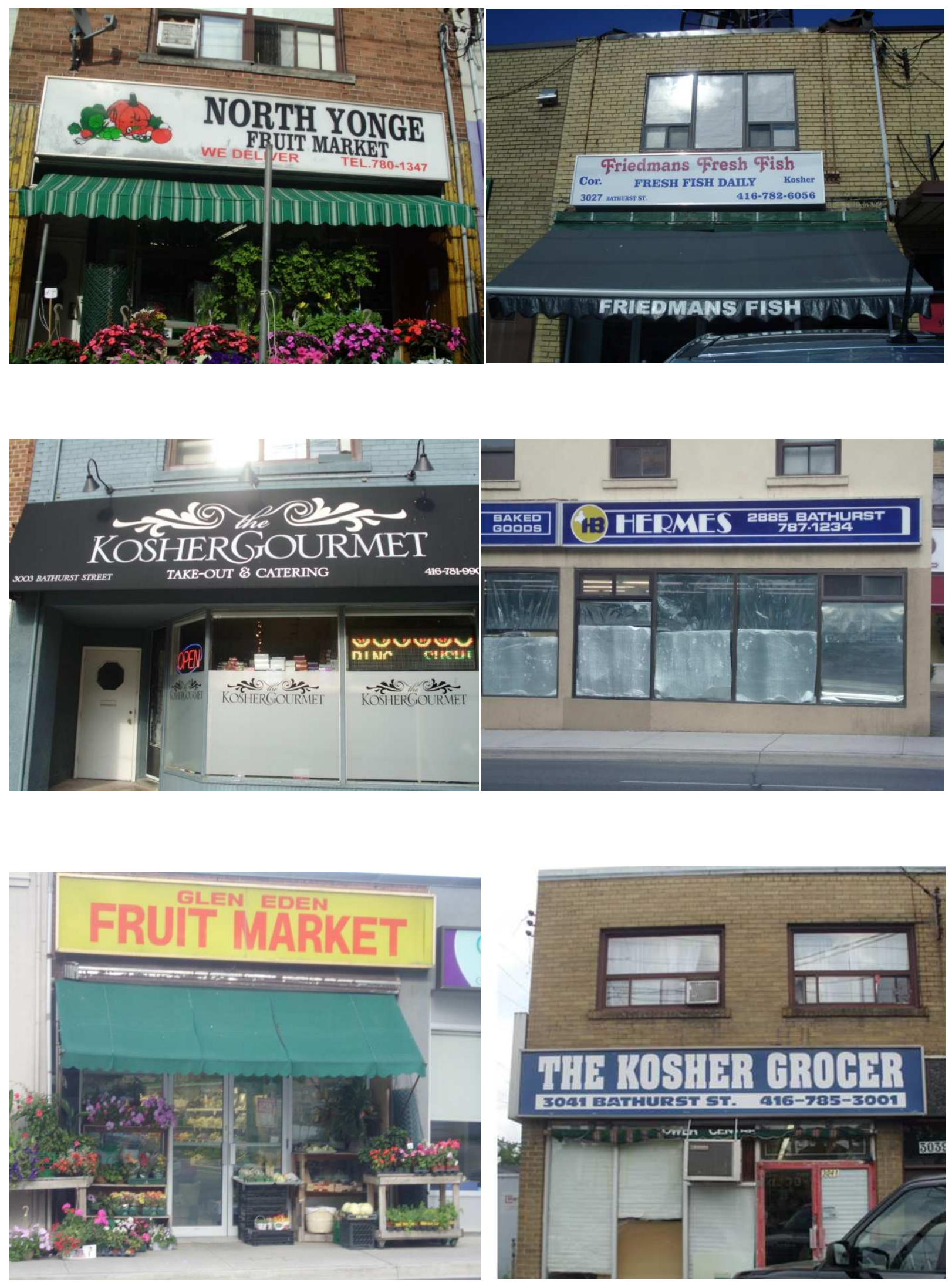


\section{References}

Access to Healthy Food Coalition (2010). Which Foods Does Access Consider Healthy or Healthier? Retrieved from

http://www.accesstohealthyfoods.org/index.php?page id=213

Addy, K., \& Pike, B. (2009). Mapping Maribyrnong. Retrieved from

http://www.maribyrnong.vic.gov.au/files/wrhc mapping maribyrnong 2009 report.pdf

Adhikari, B. (2007). Accessibility under competition: An implementation in a GIS environment, (Master thesis). School of Economic, Political and Policy Sciences. The University of Texas at Dallas.

Anthony, E., \& Lee, C. (2010). Food Desert Reduction: City of Los Angeles. Retrieved from http://www.fileden.com/files/2012/2/10/3262669//FoodDesert.pdf

Apparicio, P., Marie-Soleil, C., \& Shearmur, R. (2007). The case of Montréal's missing food deserts: Evaluation of accessibility to food supermarkets. International Journal of Health Geographics 6(4).

Apparicio, P., Abdelmajid, M., Riva, M., \& Shearmur, R. (2008). Comparing alternative approaches to measuring the geographical accessibility of urban health services: Distance types and aggregation-error issues. International Journal of Health Geographics 7(7). doi:10.1186/1476-072X-7-7

Baltimore City's Food Policy Initiative. (2010). Food Deserts in Baltimore. Retrieved from http://www.jhsph.edu/sebin/w/q/Food_Deserts_notes.pdf

Beaulac, J., Kristjansson, E., \& Cummins, S. (2009). A systematic review of food deserts: 19662007, Prevention of Chronic Disease, 6(3), 1-10.

Beaumont, J., Lang, T., Leather, S., \& Mucklow, C. (1995). Report from the policy sub-group to the nutrition task force: low income project team of the Department of health. Letchmore Heath, Watford: Institute of Grocery Distribution.

Bedore, M. (2007). Market Failure, Government Failure: Learning from Kingston's 'Food Desert' to Plan for a Just City. Retrieved from http://www.utoronto.ca/isrn/publications/WorkingPapers/Working07/Bedore07_MarketFailure.p $\underline{\mathrm{df}}$

Bitler, M., \& Haider, S. J. (2011). An Economic View of Food Deserts in the United States. Journal of Policy Analysis and Management, 153-176.

Blackston, C. (2012). Navigating Food Deserts: An Analysis of Social Characteristics and Transportation Options on Chicago's Far South Side. Retrieved from 
http://www.transportchicago.org/uploads/5/7/2/0/5720074/2b3 navigatingfooddeserts.pdf

Blanchard, T. C., \& Lyson, T. (2006). Access to Low Cost Groceries in Nonmetropolitan Counties: Large Retailers and the Creation of Food Deserts. Paper Presented at the Measuring Rural Diversity Conference, Washington, DC. Retrieved from http://srdc.msstate.edu/measuring/blanchard.pdf.

Bodor, J.N., Rose, D., Farley, T.A., Swalm, C., \& Scott, S.K. (2008). Neighbourhood fruit and vegetable availability and consumption: the role of small food stores in an urban environment. Public Health Nutrition, 11(4), 413-420.

Brown, A.F., Vargas, R.B., Alfonso Ang, A., \& Pebley, A.R. (2008). The Neighborhood Food Resource Environment and the Health of Residents with Chronic Conditions. J Gen Intern Med, 23(8),1137-1144.

Cassidy, A., \& Patterson, B. (2008). The Planner's Guide to the Urban Food System. Retrieved from http://postcarboncities.net/files/PlannersGuidetotheFoodSystem.pdf

Charreire H., Casey,R., Salze, P., Simon C., Chaix B., Weber C.,Banos, A., Badariotti, D., \& Oppert, J.M. (2011). Measuring the food environment using geographical information systems: a methodological review. Public Health Nutrition, 13(11), 1773-1785.

Chen, H. (2011). A Spatial Analysis of Discount Supermarkets and Their Implications for 'Food Deserts', (Master thesis). Ryerson University, Toronto.

Chicago Policy Research Team. (2011). Realizing Promise: Nurturing Children and Building Community in Chicago's Woodlawn Neighborhood. Retrieved from http://cprt.uchicago.edu/reports/CPRTReport-2011.pdf

Clarke, G., Eyre, H., \& Guy, C. (2002). Deriving indicators of access to food retail provision in British cities: Studies of Cardiff, Leeds and Bradford. Urban Studies, 39(11), 2041.

City of Toronto. (2008). Priority Areas through the Neighbourhood Action Plan. Retrieved from http://www.toronto.ca/demographics/priorityareas.htm

City of Toronto. (2009). Priority Investment Neighbourhoods. Retrieved from http://www.toronto.ca/demographics/pdf/priority2006/priority_areas_with_neighbourhoods.pdf

Commercial Policy Review. (2010). Phase 3B: Discussion Response Paper. Retrieved from http://www.kitchener.ca/en/insidecityhall/resources/Phase3B.pdf

Community Planning Studio. (2010). Access to Healthy Food in Prince George's County. Retrieved from http://www.arch.umd.edu/images/student-work/documents/StudioReport.Final.Color.pdf 
Coombs, N., Panther, J., Beye, J., \& Fehrenbach, A. (2010). A Spatial and Social Analysis of Food Deserts and Community Gardens in Madison, Wisconsin. Retrieved from http://minds.wisconsin.edu/handle/1793/47854

Crouch, c. (2011). Community Food Resources Report: Assessment of Access. Retrieved from http://www.phxrevitalization.org/ccsqlp/foodresources/CCS\%20Community\%20Food\%20Resou rces\%20Report_Final.pdf

Cummins, S., \& Macintyre, S. A. (2002). Systematic study of an urban foodscape: The price and availability of food in Greater Glasgow. Urban Studies, 39(11), 2115-2130.

Cummins, S., \& Macintyre, S. (2006). Food environments and obesity - neighborhood or nation? International Journal of Epidemiology, 35(1), 100-104.

Darcey, V.L. (2010). GIS Mapping of Retail Food Access to Assess Risks of (Chronic and Acute) Illness in Populations of Different Socioeconomic Status, (Master thesis). Drexel University.

Deaton, L. (2011). Urban Food and City Action: A Case Study of Baltimore City's Experience Addressing its Urban Food System and Food Desert Mapping Initiative. Retrieved from https://scholar.vt.edu/access/content/group/5b95dc6f-a3ef-4ce5-8e1a-875819148663/MNR Capstone Projects/Final Paper_Lucian Deaton Spring11.pdf

DMTI Spatial Inc. (2010). CanMap Route Logistics: Network Analyst. Version 2010.3. Markham, Ontario.

Dunn, R.A., Sharkey, J.R., Lotade-Manje, J., Bouhlal, Y., \& Nayga, R.M. (2011). Socio economic status, racial composition and the affordability of fresh fruits and vegetables in neighborhoods of a large rural region in Texas, Nutrition Journal, 10(6), 1-10.

Eartheasy. (2012). Composting. Retrieved from http://eartheasy.com/grow_compost.html

Eisenburg, D., \& Silcott, J. (2010). Grocery Access: Franklin County, OH. Retrieved from http://jennifersilcott.com/documents/Silcott_foodDesertGIS.pdf

Farley, T.A., Rice, J., Bodor, J.N., Cohen, D.A., Bluthenthal, R.N., \& Rose, D. (2009). Measuring the food environment: shelf space of fruits, vegetables, and snack foods in stores. $J$ Urban Health, 86(5), 672-682.

Food and Drug Organization. (1996). Declaration on world food security. World Food Summit, FAO, Rome.

Food Marketing Institute. (2002). New FMI Report: Most Profitable Independents Invest the Most in Employees; Study Benchmarks Financial Performance, Productivity, Inventory Management. Retrieved from http://www.fmi.org/news-room/news-archive/view/2002/12/13/new-fmi-report-most-profitable- 
independents-invest-the-most-in-employees-study-benchmarks-financial-performanceproductivity-inventory-management

Food Secure Canada. (2012). Access to Food in Urban Communities. Retrieved from http://foodsecurecanada.org/policy/3-access-food-urban-communities

Gallagher, M. (2007). Examining the impact of food deserts on public health in Detroit: Mari Gallagher Research \& Consulting Group. Chicago IL.

Gallaher, M. (2008). Food desert and food balance indicator fact sheet. Retrieved from http://www.marigallagher.com/site_media/dynamic/project_files/FdDesFdBalFactSheetMG_.pdf

Galvez, M.P., Lu Hong, L., Choi, E, Liao, L., Godbold, J., \& Brenner. B. (2009).Childhood Obesity and Neighborhood Food Store Availability in an Inner City Community. Acad Pediatr. 9(5): 339-343. doi:10.1016/j.acap.2009.05.003.

Getz, L. (2008). Food Deserts: Where Healthy Options Are Only a Mirage. Today's Dietitian, 10(10), 48.

Gillespie, I.A., Mook, P., Little, C.L., Grant, K.A. and McLauchlin, J. (2010). Human listeriosis in England, 2001-2007: association with neighbourhood deprivation. Euro Surveill,15(27).

Retrieved from:

http://www.eurosurveillance.org/ViewArticle.aspx?ArticleId=19609

Glanz, K., Sallis, J.F., Saelens, B.E., \& Frank, L.D. (2007). Nutrition environment measures survey in stores (NEMS_S). Am J Prev Med, 32(4), 282-289.

Gordon, C., Purciel-Hill, M., Ghai, N. R., Kaufman, L., Graham, R., \& Van Wye, G. (2011). Measuring food deserts in New York City's low-income neighborhoods. Health \& Place, 17(2), 696-700. doi:10.1016/j.healthplace.2010.12.012

Gregory, M. R. (2009). Environmental implications of plastic debris in marine settings entanglement, ingestion, smothering, hangers-on, hitch-hiking and alien invasions. Phil. Trans. R. Soc. B, 364, 2013-2025. doi: 10.1098/rstb.2008.0265

Gustat, J. (2012). Food Access in New Orleans. Retrieved from http://mylifecity.com/uploads/Gustat_N_O_Access_to health_foods_stakeholder_meeting_for_d istribution-1328160605.pdf

Guy, C. M., \& David, G. (2004). Measuring physical access to 'healthy foods' in areas of social deprivation: a case study in Cardiff. International Journal of Consumer Studies, 28(3), 222-234.

Hamm, M. W., \& Bellows, A. (2003). Community Food Security: Background and Future Directions. Journal of Nutrition Education and Behavior , 35 (1), 37-43. 
Health Policy Connection. (2011). How can we close the oral health gap? Retrieved from http://www.rwjf.org/files/research/howcanweclosetheoralhealthgap.pdf

Herries, J. (2010). Mapping Food Deserts. Retrieved from http://proceedings.esri.com/library/userconf/healthy-communities10/pdfs/mapping-fooddeserts.pdf

Herrington, D. (2012). Eat Real Food, Not Junk Food - Facts \& Stats. Retrieved from http://midete.org/eat-real-food-not-junk-food-facts-stats/

Hendrickson, D., Smith, C., \& Eikenberry, N. (2006). Fruit and vegetable access in four lowincome food deserts communities in Minnesota. Agriculture and Human Values, (23), 371-383.

Hewko, J., Smoyer-Tomic, K. \& Hodgson, M. J. (2002). Measuring neighbourhood spatial accessibility to urban amenities: does aggregation error matter? Environment and Planning A, $34,1185-1206$.

Hickman, M. (2007) .Campaign breakthrough as food giants agree to cut packaging. Retrieved from

http://environment.independent.co.uk/lifestyle/article2659724.ece

Hoch, S. C. (2008). Comparing Spatial Measures of the Built Environment for Health Research, (Master thesis). Department of Geography, Indiana University.

Hubley, T. A. (2011). Assessing the proximity of healthy food options and food deserts in a rural area in Maine. Applied Geography, 31(4), 1224-1231.

Jimenez, K., \& Passer, R. (2011). The Role of Fast Food in Onondaga County, NY. Retrieved from

http://www2.binghamton.edu/geography/studentprojects/passer.pdf

Just Food. (2011). OC Transpo \& Food Access. Retrieved from

http://www.justfood.ca/foodforall/weblinks/oc-transpo-food-access/

Kershaw T., Creighton, T., Markham T., \& Marko J. (2010). Food access in Saskatoon.

Saskatoon: Saskatoon Health Region. Retrieved from

http://www.saskatoonhealthregion.ca/your health/documents/PHO/CommunityFoodAccessRepo $\underline{\text { rtOct2010.pdf }}$

Knight, E., Matt Berggren, M., Causton, D., \& Fernandez, B.J. (2011). Fresh Produce and Health Care Access in Humboldt Park. Retrieved from http://gis.depaul.edu/shwang/CommunityOutreach/GEO242_Service_Learning_Project/GEO242 _Win1011_PRCC_FoodDesert_Final_Report.pdf

Koc, M., \& Welsh, J. (2002). Food, Identity and Immigrant Experience. Canadian Diversity, $1(1), 46-48$. 
Kowalesiki-Jones, L., Fan, J.X.,Yamada, I., Zick, C. D., Smith, K.R., \& Brown, B.B. (2009). Alternative Measures of Food Deserts:Fruitful Options or Empty Cupboards? Retrieved from http://www.npc.umich.edu/news/events/food-access/kowaleski-jones_et_al.pdf

Lakey, M. D. (2010). Report of the Healthy Food Advisory Committee: Fresh Food Availability in Texas. Retrieved from http://www.squaremeals.org/Portals/8/files/publications/SB\%20343\%20Final\%20Complete.pdf

Larsen, K., \& Gilliland, J. (2008). Mapping the evolution of 'food deserts' in a Canadian city: Supermarket accessibility in London, Ontario, 1961-2005. International Journal of Health Geographics, 7(16), 1-16.

Larsen, K., \& Gilliland, J. (2009). A farmers' market in a food desert: Evaluating impacts on the price and availability of healthy food. Health Place, 15(4), 1158-1162.

Larson, N. I., Story, M. T., \& Nelson, M. C. (2009). Neighborhood environments: Disparities in access to healthy foods in the U.S. American Journal of Preventive Medicine, 36(1), 74-81.

Leete, L., Bania, N., and Sparks-Ibanga, A. (2012). Congruence and Coverage: Alternative Approaches to Identifying Urban Food Deserts and Food Hinterlands. Journal of Planning Education and Research, 1-16. doi: 10.1177/0739456X11427145

Levin, M. (2011). Toward a Greater Understanding of Food Access. Retrieved from http://soac2011.com.au/files/papers/SOAC2011 0213 final.pdf

Levinson, D., \& El-Geneidy, A. (2009). The Minimum Circuity Frontier and the Journey to Work. Retrieved from http://tram.mcgill.ca/Research/Publications/Circuity_Levinson_Geneidy.pdf

Linthicum, A. (2007). Quantifying Access to Local Food. Retrieved from http://www.virginia.edu/ien/docs/07FoodClassFINAL\%20PAPERS/Access\%20to\%20Local\%20 Food.pdf

Lister, N.M. (2007). Placing Food: Toronto's Edible Landscape. Retrieved from http://www.ryerson.ca/foodsecurity/projects/urbandesign/Nina\%20Marie\%20Lister\%20paper.pd $\underline{\mathrm{f}}$

Luberichs, J., \& Wachowiak, H. (2010). GIS Supported Segmentation Study of Visitors to Majorca Island. Retrieved from

http://www.iubh.de/files/de/downloads/downloads/Sonstige\%20de/GISsupportedSegmentationSt udyofVisitorstoMajorcaIsland.pdf

Luo, L., McLafferty, S., \& Wang, F. (2010). Analyzing spatial aggregation error in statistical models of late-stage cancer risk: a Monte Carlo simulation approach. International Journal of Health Geographics , 9(51). doi:10.1186/1476-072X-9-51 
Martin Prosperity Institute (2010). Food deserts and priority neighbourhoods in Toronto. Retrieved from http://martinprosperity.org/2010/06/15/food-deserts-and-priority-neighbourhoods-in-toronto/

McCreary, T. and Briarpatch, R.M. (2006). Station 20 West is set to bloom in a (food) desert. Retrieved from http://www.actupinsask.org/index2.php?option=com_content\&do_pdf=1\&id=136

Macdonald, L., Ellaway, A., Ball, K., \& Macintyr, S. (2011). Is proximity to a food retail store associated with diet and BMI in Glasgow, Scotland? Retrieved from http://www.biomedcentral.com/1471-2458/11/464

McEntee, J., \& Agyeman, J. (2009). Towards the development of a GIS method for identifying rural food deserts: Geographic access in Vermont, USA, Applied Geography, doi:10.1016/j.apgeog.2009.05.004

McGinnis J. M., \& Nestle M. (1989). The Surgeon General's report on nutrition and health: policy implications and implementation strategies. American Journal of Clinical Nutrition, 49(1), 23-28.

Mednath. (2012). Food Desert. Retrieved from http://medanth.wikispaces.com/Food+Desert

Margheim, J. (n.d). The Grocery of Eating Well. Retrieved from http://pdx.edu/sites/www.pdx.edu.ims/files/media_assets/ims_mscape07atlas.pdf

Michimi, A. and Wimberly, M.C. (2010). Associations of supermarket accessibility with obesity and fruit and vegetable consumption in the conterminous United States. International Journal of Health Geographics, 9(1), 49.

Morland, K., Wing, S., \& Roux, A. D. (2002). The contextual effect of the local food environment on residents diets: The atherosclerosis risk in communities study. American Journal of Public Health, 92(11), 1761-1768.

Morland, K., Diez Roux, A. V., \& Wing, S. (2006). Supermarkets, other food stores, and obesity: The atherosclerosis risk in communities study. American Journal of Preventive Medicine, 30(4), 333-339.

Nabhan, G., \& Watters, K. (2011). Mom-and-pop vs. big-box stores in the food desert. Retrieved from

http://grist.org/locavore/2011-06-01-community-owned-assets-big-box-stores-will-solve-thefood-desert/

Nasr, S., Polsky, J., Patychuk, D., \& Sopher, L. (2011). Food Mapping and Access to Healthy Food/Food Security. Retrieved from

http://www.intohealth.ca/wpcontent/uploads/Health Action Areas/Food Mapping Healthy Eati ng Food Security.pdf 
Nazz, S. (2012). How eating junk food threatens the environment. Retrieved from http://www.ecofriend.com/eating-junk-food-threatens-environment.html

Neckerman, K.M., Bader, M., Purciel, M., \& Yousefzadeh, P. (2009). Measuring Food Access in Urban Areas, National Poverty Center Working Paper. Retrieved from

www.npc.umich.edu/news/events/food-access/index.php

Nikhanj, S. D. (2010). Alleviating Urban Food Deserts: Lessons from the Literature, (Master thesis). University of Pittsburgh.

O’Dwyer LA \& Coveney J (2006) Scoping supermarket availability and accessibility by socioeconomic status in Adelaide. Health Promot J, 17(3), 240-246.

Oliver, L.N., Schuurman, N., \& Hall, A.W. (2007). Comparing circular and network buffers to examine the influence of land use on walking for leisure and errands. Int J Health Geogr, 6, 41.

Opfer, P.R. (2010). Using GIS Technology to Identify and Analyze 'Food Deserts' on the Southern Oregon Coast, (Master thesis). Oregon State University.

Parsons, S. (2012). An Evaluation of the Food Desert Definition in Durham, North Carolina, (Master thesis). Nicholas School of the Environment, Duke University.

PlaNYC. (2011). Urban Food Policy. Retrieved from

http://www.urbanfoodpolicy.com/2011/04/planyc-2030-update-food-edition.html

Policy Link. (2009). Healthy Food, Healthy Communities: Promising Strategies to Improve Access to Fresh, Healthy Food and Transform Communities. Retrieved from http://www.policylink.org/site/c.lkIXLbMNJrE/b.5136441/k.BD4A/Home.htm

Raja, S., Yin, L., Roemmich, J., Ma, C., Epstein, L., Yadav, P., \& Ticoalu, A. (2010). Food Environment, Built Environment, and Women's BMI: Evidence from Erie County, New York. Journal of Planning Education and Research, 29(4), 444-460.

Ramos, C., Sibanda, P., State, H., \& Van Dorp, J. (2008). Assessing and Addressing Food Security in North Kingston: Challenges and Opportunities for the Community and Beyond. Retrieved from http://business.kingstoncanada.com/en/reportstudies/resources/Assessing\%20and\%20Addressing \%20Food $\% 20$ Security $\% 20$ in $\% 20$ North $\% 20$ Kingston.pdf

Regional Food Policy Council, (2011). Identifying Food Deserts: Access to Healthy Food in Puget Sound Region, Department of Urban Design and Planning, University of Washington. Retrieved from http://courses.washington.edu/studio67/psrcfood/Food_studio_docs/Vol05_Food_Deserts.pdf

Reisig, V., \& Hobbiss, A. (2000) Food deserts and how to tackle them: a study of one city's approach. Health Education Journal, 59(2), 137-149. 
Richner, L. (2012). Farmers' Markets: The Potential Cure for Food Deserts? Retrieved from http://notenoughgood.com/2012/01/food-deserts/

Robinson, W. S. (1950). Ecological correlations and the behavior of individuals, American Sociological Review, 15, 351-357.

Rose, D., Bodor, J.N., Swalm, C.M., Rice, J.C., Farley, T.A., and Hutchinson, P.L. (2009). Deserts in New Orleans? Illustrations of urban food access and implications for policy. Retrieved from http://www.npc.umich.edu/news/events/food-access/rose et_al.pdf

Rundle, A., Neckerman, K. M., Freeman, L., Lovasi, G. S., Purciel, M., Quinn, J., Richards, C., Sircar, N., Weiss, C. (2009). Neighborhood Food Environment and Walkability Predict Obesity in New York City. Environmental Health Perspectives, 117(3), 442-447.

Russell, S.E., \& Heidkamp, C.P. (2011). 'Food desertification' - The loss of a major supermarket in New Haven, Connecticut. Applied Geography, 31 (4), 1197-1209.

Saelens , B. E., Sallis, J.F., \& Frank, L.D. (2003). Environmental correlates of walking and cycling: findings from the transportation, urban design, and planning literature. Ann Behav Med, $25,80-91$.

Schlundt, D. (2010). Selection of Food Deserts for Nashville's Communities Putting Prevention to Work. Retrieved from http://www.healthynashville.org/javascript/htmleditor/uploads/CPPWFoodDeserts.pdf

Seliske, L.M. (2012). The Built Environment and Obesity-related Behaviors in Canadian Youth, (Doctoral dissertation). Queen's University Kingston, Ontario.

Sharkey, J.R., \& Horel, S. (2009). Characteristics of Potential Spatial Access to a Variety of Fruits and Vegetables in a Large Rural Area. Paper presented at: Understanding the Economic Concepts and Characteristics of Food Access, Washington, DC. Retrieved from http://www.npc.umich.edu/news/events/food-access/sharkey.pdf.

Shaw, H. (2006). Food deserts: Towards the development of a classification. Geografiska Annaler Series B - Human Geography, 88B (2), 231-247.

Short, Anne., Guthman, J., \& Raskin. S. (2007). Food deserts, oases, or mirages? Journal of Planning Education and Research, 26 (3), 352-64.

Smoyer-Tomic, K., Spence, J. \& Amrhein, C. (2006). Food deserts in the Prairies? Supermarket accessibility and neighborhood need in Edmonton, Canada, The Professional Geographer, 58(3), 307-326. 
Sparks, A.L. (2008). Measuring Food Deserts: A Comparison of Models Measuring the Spatial Accessibility of Supermarkets in Portland, Oregon, (Master thesis). Department of Planning, Public Policy and Management, University of Oregon.

Sparks, A.L., Bania, N., \& Leete, L. (2011) Comparative Approaches to Measuring Food Access in Urban Areas: The Case of Portland, Oregon. Urban Studies, 48(8), 1715-1737.

Sprigler, T, L. (2011). River City Food: Assessing Food Access and Production in Downtown New Albany, Indiana (Master thesis). Retrieved from

http://proquest.umi.com/pqdlink?did $=2550175401 \& \mathrm{Fmt}=7 \&$ clientId $=79356 \& \mathrm{RQT}=309 \& \mathrm{VNam}$ $\underline{\mathrm{e}=\mathrm{PQD}}$

Stan, V., Virsta, A., Dusa, E. M., \& Glavan, A.M. (2009). Waste Recycling and Compost Benefits. Not. Bot. Hort. Agrobot. Cluj, 37 (2), 9-13.

Statistics Canada. (2012). North American Industry Classification System, Canada 2012. Ottawa: Statistics Canada, Standards Division. Retrieved from http://www.statcan.gc.ca/pub/12-501-x/12-501-x2012001-eng.pdf

Sterling, J., \& Grover, B. (2011). US: New initiative to provide health food to underserved communities. Retrieved from

http://www.procor.org/news/news_show.htm?doc id=1615610

Stilley, M. (2012). Urban Food Deserts: An Exploration of Northern Neighborhoods in Denver, (Master thesis). University of Colorado, Denver.

Thierolf, A. (2012). The Nebraska Sandhills Food Desert: Causes, Identification, and Actions towards a Resolution (Master thesis). University of Nebraska, Lincoln.

Thomas, B. (2004). The relationship among household characteristics, geographic space, and food security in the Allen Neighborhood. Retrieved from

http://www.allenneighborhoodcenter.org/wp-content/uploads/2010/01/2004-Brian-Thomas-

$\underline{\text { Study-of-ANC-Food-Security.pdf }}$

Thornton, L.E., Pearce, J.R., \& Kavanagh, A.M. (2011). Using Geographic Information Systems (GIS) to assess the role of the built environment in influencing obesity: a glossary, International Journal of Behavioral Nutrition and Physical Activity, 8(71), 1-9.

Toronto Community Health Profile. (2011). Englemount-Lawrence Profile: Sociodemographic. Retrieved from

http://torontohealthprofiles.ca/a documents/HPD_neighb_data/HPD_neighb_SocDem_data/HP D_neighb_SocDem_2006/HPD_neighb_SocDem_2006 32.pdf

Traub, A. E. (2011). Farmers Markets as a Healthy Food Access Strategy: Assessing Baltimore's Farmers Markets \& Proposing Recommendations to Increase Access. Retrieved from http://ocw.jhsph.edu/courses/capstone2011/PDFs/Traub_Arielle_2011.pdf 
Trimarchi, M. (2008). What is a food desert? Retrieved from http://science.howstuffworks.com/environmental/green-science/food-desert.htm

United States Department of Agriculture. (2008). Dietary Guidelines for Americans. Retrieved from http://www.cnpp.usda.gov/DietaryGuidelines.htm

Vallianatos, M., Shaffer, A., Beery, M., Gottlieb, R., \& Wheatley, A. (2004). Thinking Outside The Box: Impacts of and Alternative to The WAL-MART Way Food Access, Labor and Land Use. Retrieved from http://www. uepi.oxy.edu

Van Meter, E. M., Lawson1, A. B., Colabianchi, N., Nichols, M., Hibbert, J., Porter, D. E., \& Liese, A. D. (2010). An evaluation of edge effects in nutritional accessibility and availability measures: a simulation study. International Journal of Health Geographics, 9(40).

doi:10.1186/1476-072X-9-40

Ver Ploeg, M. (2009). Access to Affordable and Nutritious Food: Measuring and Understanding Food Deserts and Their Consequences. Economic Research Service. Report to Congress. Retrieved from http://www.ers.usda.gov/publications/ap/ap036/ap036.pdf

Waches, M., \& Kumagi, T.G. (1973). Physical Accessibility as a Social Indicator. Socioeconomic Planning Science, 7, 437-456.

Weatherspoon, D., Weatherspoon, L., Oehmke, J. (2011). Food Deserts \& Food Security (Economic, Social, Health and Environmental Impacts of Imbalances in Access and Demand). Retrieved from http://www.mihelp.org/pdf files/2010\%20Seminar\%20Series/fddeserts\&fdsecurity mihelpsemi nar_weatherspoonetal_021810.pdf

Wendt, M., Kinsey, J., \& Kaufman, P. (2008). Food Accessibility in the Inner City:

What Have we Learned? A Literature Review 1963-2007. Retrieved from http://ageconsearch.umn.edu/bitstream/37625/2/tr08-01a.pdf

White, M., Bunting, J., Williams, L., Raybould, S., Adamson, A., \& Mathers, J. (2004). Do 'food deserts' exist? A multi-level, geographical analysis of the relationship between retail food access, socioeconomic position and dietary intake. Final Report to the Food Standards Agency. University of Newcastle upon Tyne.

White, M. (2007). Food access and obesity. Obesity Reviews, 8 Supplement 1, 99-107.

Wintle, S. (2010). Finding food deserts: A spatial analysis of food security in Northwestern Ontario (1996 -- 2006), (Master thesis). Lakehead University, Ontario.

Wong, D.W. S. \& Wu, C. V. (1996). Spatial Metadata and GIS for Decision Support. Spatial Metadata and GIS for Decision Support. In: Proceedings of the 29th Annual Hawaii International Conference on System Sciences. IEEE. 
Woodham, C. (2009). Food Desert or Food Swamp? An In-depth Exploration of Neighbourhood Food Environment in Eastern Porirua and Whitby, (Master thesis). University of Otago, Dunedin, New Zealand: Wellington: Wellington.

Wrigley, N., Warm, D., Margetts, B., \& Whelan, A. (2002). Accessing the impact of improved retail access on diet in a 'food desert': a preliminary report, Urban Studies, 39(11), 2061-2082.

Wrinkler, E. A. (2012). Food Accessibility, Availability, Cooking Skills and Socioeconomic Differences in Fruit and Vegetable Purchasing in Brisbane, Australia, (Doctoral dissertation). Retrieved from http://eprints.qut.edu.au/17016/1/Elisabeth_A._H._Winkler_Thesis.pdf

Yousafzai, W., Viscontas, T., Sandercott, R., Chang, S., \& Wu, J. (2009). Food Deserts Plan 233: People and Plans. Retrieved from http://waqas.ca/wpca/wp-content/uploads/2010/12/Food-Deserts-in-Region-of-Waterloo.pdf

Zenk, S., Schulz, A., Israel, B., James, S., Bao, S., \& Wilson, M. (2005). Neighborhood racial composition, neighborhood poverty, and the spatial accessibility of supermarkets in metropolitan Detroit. American Journal of Public Health, 95(4), 660-667. 